ISSN (print): 1698-6180. ISSN (online): 1886-7995

www.ucm.es/info/estratig/journal.htm

Journal of Iberian Geology 38 (1) 2012: 85-111

http://dx.doi.org/10.5209/rev_JIGE.2012.v38.n1.39207

\title{
Contribution of active faults in the intraplate area of Iberia to seismic hazard: The Alentejo-Plasencia Fault
}

\author{
Contribución a la peligrosidad sísmica de las fallas activas de la zona \\ intraplaca de Iberia: la Falla Alentejo-Plasencia
}

\author{
P. Villamor ${ }^{1}$, R. Capote ${ }^{2}$, M.W. Stirling ${ }^{1}$, M. Tsige ${ }^{2}$, K.R. Berryman ${ }^{1}$, J.J. Martínez-Díaz ${ }^{2}$, \\ F. Martín-González ${ }^{3}$ \\ ${ }^{1}$ GNS Science, PO Box 30-368, Lower Hutt, New Zealand \\ ${ }^{2}$ Dpto. Geodinámica. Facultad de CC. Geológicas. Universidad Complutense de Madrid. \\ c/ José Antonio Novais, 2. 28040 Madrid, Spain. \\ ${ }^{3}$ Área de Geología. ESCET. Universidad Rey Juan Carlos. C/Tulipán, s/n. Móstoles, 28933 Madrid, Spain.
}

*Corresponding author: p.villamor@gns.cri.nz

Received: 24/12/11 / Accepted: 21/04/12

\begin{abstract}
We present the earthquake potential characterisation of the Alentejo-Plasencia Fault (APF) in the intraplate area of the Iberian Peninsula. The APF displays clear deformation of geomorphic surfaces and sediments of Neogene and younger age and, thus, we consider it to be active within the current tectonic regime. APF fault slip rate values range from 0.01 to $0.1 \mathrm{~mm} / \mathrm{yr}$ with a preferred value of $0.05 \mathrm{~mm} / \mathrm{yr}$. Mw associated to fault rupture ranges from 6.6 to 8.7 using different segmentation models (segments ranging from 20 to $500 \mathrm{~km}$ ) and various fault scaling relationships. Recurrence intervals derived from slip rate and Mw range from $10 \mathrm{ka}$ to $4 \mathrm{Ma}$, with preferred values between 20 and $30 \mathrm{ka}$. Other faults in the interior of Iberia present similar values. Hazard curves produced using all fault sources from the intraplate Iberia show that active faults of the intraplate Iberia do not contribute significantly to seismic hazard at short return periods typical of the building codes ( $~ 500$ year return periods). However, they can be important contributors to hazard at critical facilities (high hazard dams, nuclear power plants, emergency response buildings) where return periods of interest may be 10,000 years or more. Our fault source characterisation is very preliminary (with large uncertainties) and further detailed studies of active faults across the whole plate boundary are required to confirm the values for the intraplate faults presented here.
\end{abstract}

Keywords: Alentejo-Plasencia Fault, active fault, intraplate Iberia, hazard assessment, Spain

Resumen

En este trabajo se presenta la caracterización del potencial sísmico de la falla Alentejo-Plasencia (APF) situada en la región intraplaca de la Península Ibérica. La APF muestra una clara deformación de superficies geomorfológicas y sedimentos de edad neógena 
y más reciente, de modo que la consideramos una falla activa dentro del régimen tectónico vigente. Los valores de velocidad de movimiento de la APF van de 0.01 a $0.1 \mathrm{~mm} / \mathrm{yr}$ con un valor preferido de $0.05 \mathrm{~mm} / \mathrm{yr}$. El valor de magnitud Mw asociada a la falla oscila entre 6.6 y 8.7 utilizando diferentes modelos de segmentación (con longitudes de segmento que van de 20 a $500 \mathrm{~km}$ ) y varias relaciones de escala. Los intervalos de recurrencia derivados de la velocidad de movimiento y de la Mw oscilan de $10 \mathrm{Ka}$ a $4 \mathrm{Ma}$, estando los valores preferidos entre los $20 \mathrm{Ka}$ y los $30 \mathrm{Ka}$. Otras fallas en el interior de Iberia presentan valores similares. Las curvas de peligrosidad generadas utilizando todas las fallas-fuente de la zona intraplaca de Iberia muestran que las fallas activas de esta zona no contribuyen de forma significativa a la peligrosidad sísmica para los cortos periodos de retorno generalmente considerados en los códigos de construcción (para períodos de retorno de $\sim 500$ años). Sin embargo, dichas fallas pueden contribuir de modo importante a la peligrosidad sísmica para instalaciones críticas (presas de elevado riesgo, centrales nucleares, edificios de servicios de emergencia) donde los periodos de retorno de interés pueden ser de 10.000 años o más. Nuestra caracterización de la falla como fuente sismogénica es muy preliminar (presenta importantes incertidumbres) y se requieren estudios detallados adicionales de las fallas activas a lo largo de todo el límite de placa para confirmar los valores de las fallas intraplaca presentados aquí.

Palabras clave: Falla de Alentejo-Plasencia, falla activa, intraplaca ibérica, peligrosidad sísmica, España.

\section{Introduction}

The Alentejo-Plasencia Fault (APF; a.k.a. Messejana or Plasencia Fault; Fig. 1) is by far the longest $(>500 \mathrm{~km})$ tectonic structure of the Iberian Peninsula. Although there is little current seismicity directly associated with the fault (Fig. 2), its remarkable geomorphic expression suggests that it is potentially active. In several low to moderate seismicity settings, large earthquakes have occurred on structures that, prior to rupture, were not identified as active (e.g.: the 1988 Tennant Creek Earthquake in central Australia; Crone et al.,. 1992; and the 2010 Darfield Earthquake, South Island, New Zealand; Quigley et al., 2010; 2012). Subsequent studies on those faults suggest that some may not have moved for tens of thousands to hundreds of thousands of years prior to the historic event (Crone et al., 1992; Villamor et al., 2011; 2012). A long fault rupture recurrence time, together with fault scarp erosion or burial processes that are faster than the slip rate of the fault, can lead researchers to underestimate the activity of intraplate faults. Moreover, faults with strikeslip motion that do not create significant relief or generate sediments associated with their tectonic activity are likely to be assessed as inactive faults. For low slip rate faults, the historic record is always short compared to the fault rupture recurrence, and thus historic seismicity usually cannot shed light on fault activity rates.

Major earthquakes associated with an active fault will pose a risk to society if rupture occurs within the design life of the structure. For typical residential buildings a 50-100 year design life is often considered and design codes often consider an earthquake with a $10 \%$ chance of occurrence in the design life as a life safety criteria (i.e., a return period of 500-1000 years; Eurocode 8, 2006). The typical return period of interest for emergency response facilities (buildings that are expected to remain serviceable through an earthquake, such as hospitals, fire and ambulance stations, and critical infrastructure facilities such as large dams or nuclear power plants) is longer, often of the order of $10 \%$ probability of occurrence in 250-1000 years (2500 to 10,000 year return period - note that in Spain hospitals are design from 1000 yr return period, NCSE02, 2002). The contribution to the different levels of seismic hazard (i.e., different return periods) from a individual earthquake source such as an active fault depends on the rate of activity of that fault. Therefore, is crucial to understand the rate of activity of faults in a region to be able to undertake robust seismicresistant design.

In this study, we present a preliminary earthquake characterisation of the Alentejo-Plasencia Fault (APF), focused on the key hazard parameters of fault slip rate and maximum earthquake magnitude. In the vicinity of the APF, there are several hydro dams, a nuclear power plant and numerous heritage buildings (including some world heritage cities, UNESCO, 2011). The presence of critical facilities and world heritage buildings close to the fault necessitates an evaluation of future earthquake potential. We have compiled data from the APF and other faults in the area (Fig. 1; Appendix 1), and undertaken an assessment of the contribution of APF and similar slow faults to the seismic hazard of central and western Iberia. Finally, we compare the rates of tectonic activity assigned to faults in the intraplate area of Iberia and consider whether the strain budget of the intraplate region compared to the total plate boundary budget is reasonable.

\section{Geological setting}

In the intraplate area of the Iberian Peninsula (western and central Iberia), seismicity is low to moderate with the largest instrumental record of MbLg 5.1 in 1997 (Lugo Earthquake; Martínez-Díaz et al., 2006) (Fig. 2). The 
Fig. 1.- Main faults of the Iberian Massif (MOPT, 1992). In red line are potencially active faults: 1) Ventaniella, 2) Asturias central (Franja Movil Intermedia), 3) Asturias Occidental (Espina), 4) Borde Norte de la Cuenca del Duero, 5) Sabero-Gordón, 6) León, 7) Porma, 8) Bierzo, 9) Galicia Norte, 10) Galicia Sur, 11) Galicia Central, 12) Sarria , 13) Montforte, 14) Borde Sur del Sistema Central, 15) Borde Norte del Sistema Central, 16) Seisa-Lousa, 17) SobreiraFormosa-Pomar-Grade, 18) Ponsul, 19) Nazaré-Pombal, 20) Sierra Albarrana, 21) Las Portillas, 22) Monte Chaõ, 23) Manteigas-Vilariça-Baragança, 24) Penacova-ReguaVerín, 25) Borde Norte de la Cuenca del Guadiana, 26) Béjar, 27) Vidigueira-Moura, 28) Grandola, 29) Río SorMontargil, 30) Tejo Inferior, 31) Alentejo-Plasencia. Digital elevation model from SGE (1997).

Fig. 1.- Principales fallas del Macizo Ibérico (MOPT, 1992). Las líneas rojas muestran las fallas potencialmente activas: 1) Ventaniella, 2) Asturias central (Franja Movil Intermedia), 3) Asturias Occidental (Espina), 4) Borde Norte de la Cuenca del Duero, 5) Sabero-Gordón, 6) León, 7) Porma, 8) Bierzo, 9) Galicia Norte, 10) Galicia Sur, 11) Galicia Central, 12) Sarria , 13) Montforte, 14) Borde Sur del Sistema Central, 15) Borde Norte del Sistema Central, 16) Seisa-Lousa, 17) Sobreira-Formosa-Pomar-Grade, 18) Ponsul, 19) Nazaré-Pombal, 20) Sierra Albarrana, 21) Las Portillas, 22) Monte Chaõ, 23) Manteigas-Vilariça-Baragança, 24) Penacova-Regua-Verín, 25) Borde Norte de la Cuenca del Guadiana, 26) Béjar, 27) Vidigueira-Moura, 28) Grandola, 29) Río Sor-Montargil, 30) Tejo Inferior, 31) Alentejo-Plasencia. Modelo digital de elevaciones de SGE (1997).

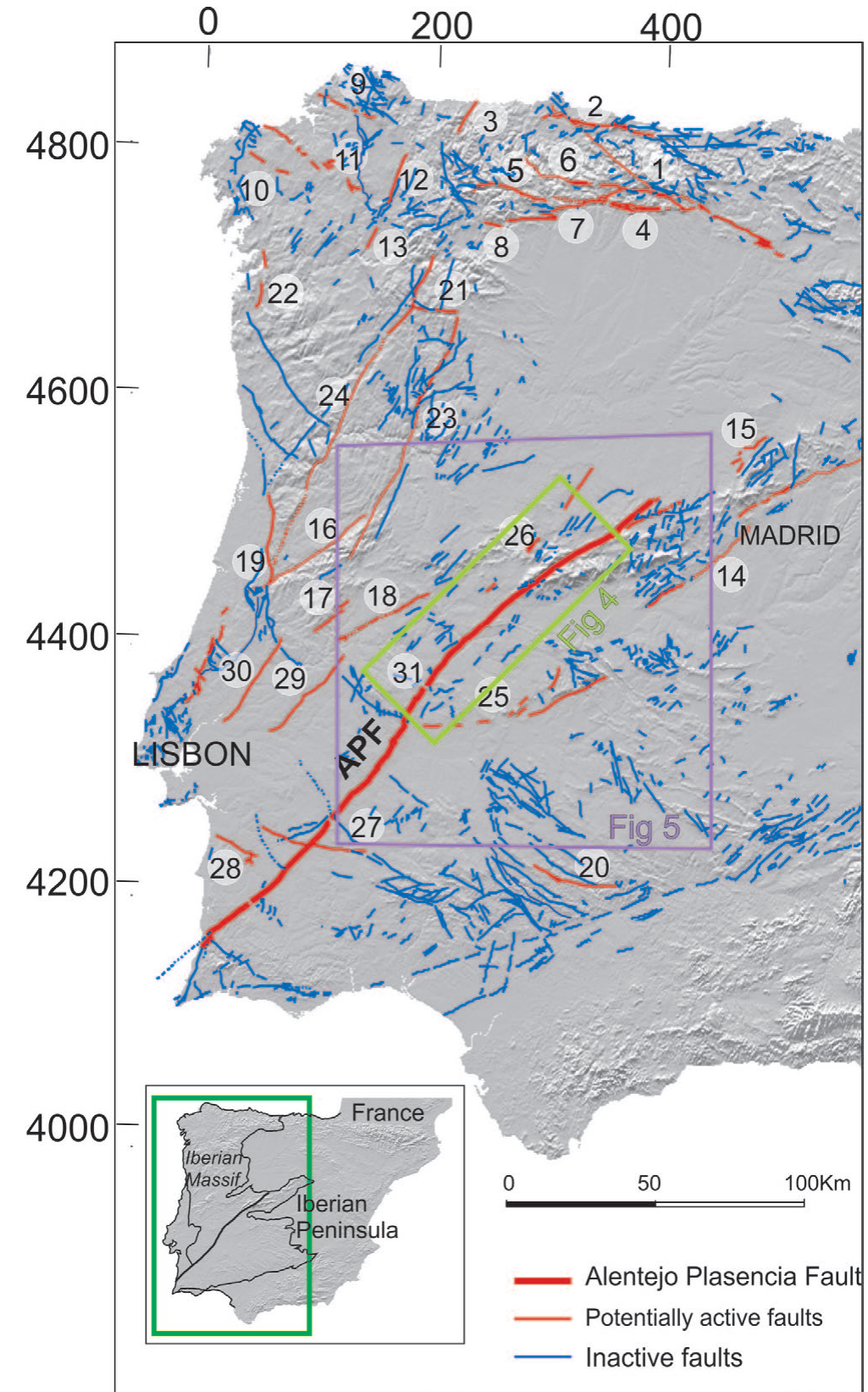

described three different phases for the evolution of the Spanish Central Mountainous System (the main mountain range bounding large basins in Central Iberia): the Oligocene to Early Miocene Iberian Stage, the Middle to late Miocene Guadarrama Stage, and the Torrelaguna Stage from late Miocene to the Present. The first stage is associated with the collision between Eurasia and Iberia; the second and third with the collision between Iberia and Africa. Other authors present similar tectonic phases for surrounding areas. For example, Muñoz-Martín and De Vicente (1998) and De Vicente et al. (2004) describe two phases, Pyrenean (Eocene-Oligocene) and Betic (Middle Miocene to present) that approximately correspond to the Iberian and the Guadarrama-Torrelaguna stages described above. Capote et al. (2002 and references therein), for example, conformities within the basins (De Vicente et al., 2011).

plate boundary lies more than $300 \mathrm{~km} \mathrm{SE}$ of the study , and relative plate motion rates between the collidyr (DeMets et al., 1990; 1994). Fault activity rates in e study area are low (see below) and there have been no fault ruptures. Historical seismicity earthquake intensity from an inland event is MMI IX (the Villa Franca de Xira, Portugal, Earthquake in 1531; Matínez Solares and Mezcua, 2002).

The Tertiary tectonic evolution on the central part of the Iberian Peninsula is recorded by deformation at faults bounding major sedimentary basins and sedimentary un- 
NE trending strike-slip faults are conspicuous in the Iberian Massif (the Variscan basement of the Iberian Penisula) (Fig. 1). In Portugal, vertical displacement along those faults has been dated as Upper Miocene-Quaternary (Cabral, 1989; Carvalho et al., 2006). In the NW of the Iberian Massiff, NE trending faults are associated with active intraplate seismicity (González-Casado and Giner Robles, 2000; Rueda and Mezcua, 2001; López-Fernández et al., 2004; Martínez-Díaz et al., 2006). In this latter area, the drainage pattern has also been described as controlled by NE-SW faults (Martín-González, 2009). More recent paleoseismic studies have revealed the Quaternary activity of the Vilariça fault (NE trending fault; fault 23 on Fig 1), with at least two $\mathrm{Mw}>7$ events in the last $14.5 \mathrm{ka}$ with a slip rate of $0.3-0.5 \mathrm{~mm} / \mathrm{yr}$ (Rockwell et al., 2009).

\subsection{Geological History of the APF}

Based on the similarity of the APF with other NE trending faults of the central/western part of the Iberian Peninsula, several authors considered the APF to have formed during a dominant strike-slip regime at the end of the Variscan orogeny (Late Carboniferous to Permian; Parga Pondal, 1969; Arthaud and Matte, 1975). The $\mathrm{NE}$ trending faults in the region are associated with late Carboniferous to Permian sediments, and have different total displacements associated with different age granitic formations (co- and post- Variscian Orogeny batholiths).

The APF is associated with a Mesozoic dike along its entire length (Fig. 3). The presence of a large fault in association with a Mesozoic basic dike, the Messejana dike, was described as early as 1950s (Del Valle Lersundi, 1959; Quesada García, 1960; García de Figuerola, 1963; 1965; Parga Pondal, 1969; Arthaud and Matte, 1975; Vegas, 1974; 1975). The dike, dated as Jurassic, is associated with the opening of the Atlantic Ocean (Ziegler, 1989; Stampfli and Borel, 2002). Because of the late Carboniferous to Permian age assigned to the APF in early studies, the dike was interpreted to have intruded along the fault (Arthaud and Matte, 1975).

Studies subsequent to Arthaud and Matte (1975) have mapped the Spanish part of the APF in detail, and suggested that the fault postdates the emplacement of the dike (i.e., post-Jurassic) and that its main period of movement is more likely to be Tertiary (Capote et al., 1996; Capote and Villamor, 1999; Villamor, 2002). No late Carboniferous-Permian sediments and/or differential displacements on different aged granitic batholiths associated with the APF have been found (Villamor, 2002). Pull-apart basins along the APF are the result of left lateral movement of the fault and they contain Tertiary-Quaternary sediments
(Fig. 4). The geometric relationship between the dike and the fault has also been redefined and shows that the dike and the fault are spatially separated by $<2 \mathrm{~km}$ distance (Capote and Villamor, 1999). The dike did not intrude along the fault plane and the fault clearly displaces the dike (i.e., postdates it). These new interpretations of the history of the APF are relevant to active faulting studies because they suggest that movement along the fault is relatively recent and that the fault may still be active.

Two phases of movement on the APF have been described (Villamor, 2002). The first phase started sometime after emplacement of the Jurassic dike to Early Miocene, during the Eurasia-Iberia collision which created large basins associated with long-wavelength folding in the region (Capote et al., 2002). The APF has been interpreted to have moved during this phase with a left-lateral movement displacing the large basins. The collision at the SE boundary of Iberia from Middle Miocene onwards restructured the region and produced a long wave length curvature in the fault facilitating the creation of pull-apart basins with further left-lateral movement along the fault. Deposition of Miocene sediments is associated to the formation of pull-apart basins. In some pull-apart basins, subsidence preserved the Eocene to early Miocene sediments beneath the Middle Miocene and younger sediments.

The first studies that considered the current activity of the APF were on the Portuguese sector of the fault (Pimentel and Azevedo, 1989; 1992; 1994; Brum da Silveira, 1990; Cabral, 1995; Pimentel, 1997). Cabral (1995) described fault displacements that postdate late Pliocene sediments and geomorphic surfaces in the northernmost sector of the APF in Portugal, from Campomaior to Ervidel (Fig. 3). Tertiary sediments are preserved (mainly on the SE side of the fault) at some locations, as a consequence of post late Pliocene vertical offsets of the order of 20-60 m. Post-Miocene push-up structures are described within this sector (Brum da Silveira, 1990). At some locations Early Quaternary sediments do not seem to be displaced by the fault (Cabral, 1995).

The APF in Portuguese territory is characterised by obvious recent displacements that led Cabral (1995) to suggest that the fault is more active in the southwest part of the fault. Pimentel and Azevedo (1992; 1994) and Pimentel (1997) established the role of the APF in the formation and evolution of the Sado Basin (Fig. 3) as a basin bounding fault. The Sado Basin formed during the Paleogene as a consequence of subsidence on the hanging wall of reverse faults oblique to the APF. The APF played a secondary role as a normal fault bounding the basin at this stage. During the last major restructuring of the basin (from $10 \mathrm{Ma}$ to the present), subsidence of the 


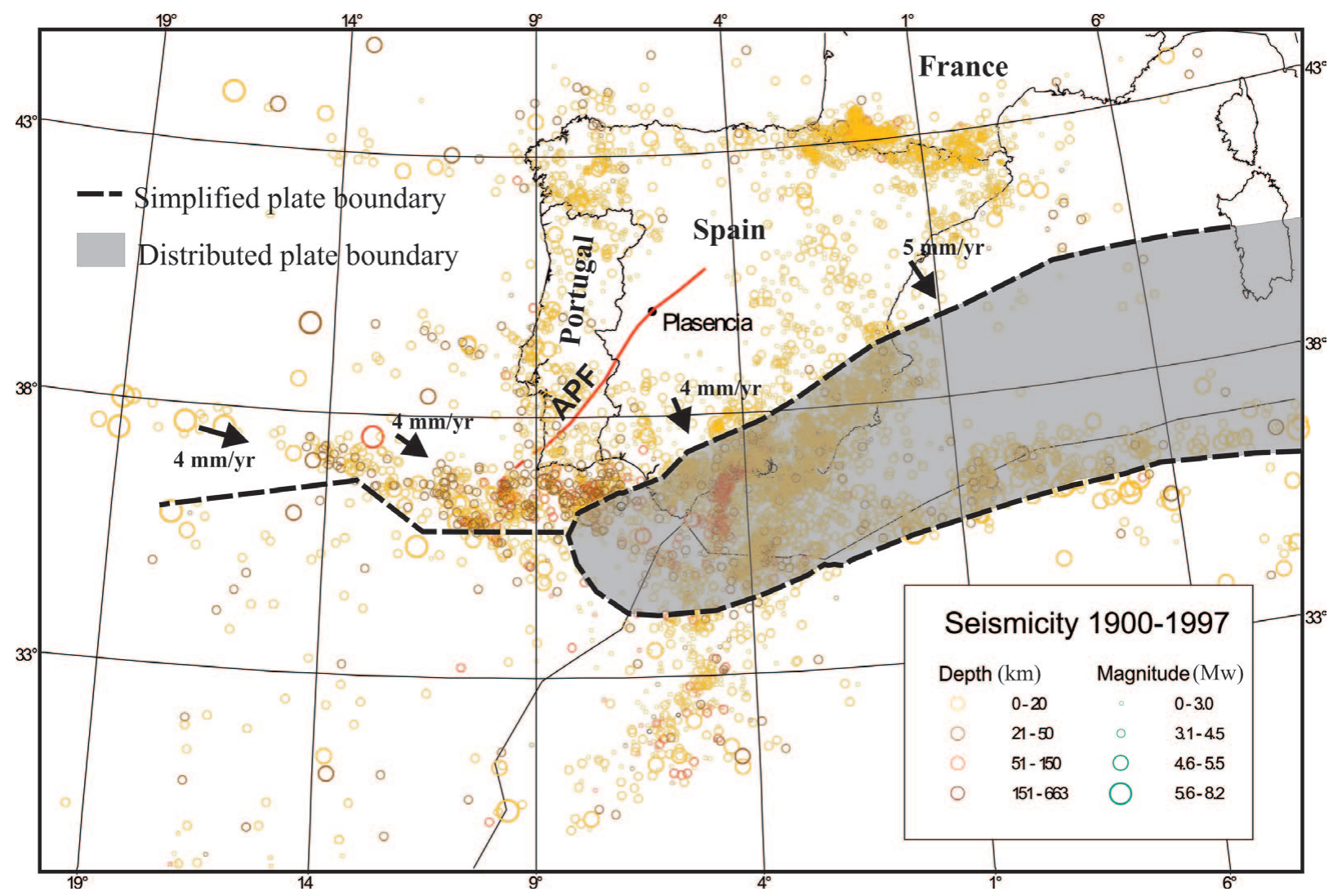

Fig. 2.- Seismicity of the Iberian Peninsula and location of the Alentejo-Plasencia fault. Note the lack of seismicity along the central and northern sector of the fault. Seismicity from IGN (Instituto Geográfico Nacional de España). Plate motions from DeMets et al. (1990; 1994). Fig. 2.- Sismicidad de la Península Ibérica y localización de la falla de Alentejo-Plasencia. Nótese la ausencia de sismicidad a lo largo de los sectores central y septentrional de la falla. La sismicidad procede del IGN (Instituto Geográfico Nacional de España). Movimientos de placas extraídos de DeMets et al. (1990; 1994)

basin took place across the APF (Pimentel, 1997). Sediments $<1.5 \mathrm{Ma}$ in age are displaced by the APF and two other sub-parallel faults. Along the southern sector of the fault onshore, post late Pliocene vertical displacement of the fault (up to $80 \mathrm{~m}$ ) provide a Quaternary vertical slip rate of 0.04 to $0.05 \mathrm{~mm} / \mathrm{yr}$. Net displacements of 0.056 to $0.07 \mathrm{~mm} / \mathrm{yr}$ were derived from vertical slip rate and slickenside orientations (Cabral, 1995).

\section{Geometry and segmentation of the APF}

Along its entire length, the APF is sub-parallel to the Messejana Dike. The fault is $500 \mathrm{~km}$ long onshore and possibly $100 \mathrm{~km}$ more offshore (Cabral, 1995). The faultdike couplet forms a clear narrow trough in the landscape (Fig. 5). The APF structure in detail consists locally of one to several sub-parallel fault traces over a width of $\leq$ $2 \mathrm{~km}$. In some areas, where there are several sub-parallel traces, it is difficult to discern the main fault traces from secondary traces.

The APF can be divided in three sectors, two in Spain and one in Portugal, based on its azimuth and broad ge- ometry (Figs. 3 and 5). The Spanish sectors will be referred to as northern and central, and the Portuguese sector as southern. The northern sector extends from the margin of the Duero Basin to the city of Plasencia (Fig. 3). The fault crosses the Spanish Central Mountain System (SCMS in Fig. 5) and displays as a linear trace with a constant $\mathrm{N} 55^{\circ} \mathrm{E}$ azimuth. In the central sector, from Plasencia city to the border with Portugal, the fault crosses the Extremadura Meseta (EM in Fig. 5) and has a curved trace with an azimuth changing from $\mathrm{N} 55^{\circ} \mathrm{E}$ at the northern end to $\mathrm{N} 30^{\circ} \mathrm{E}$ at the south. The Portuguese sector is not described in detail in this study, but a general assessment of the 1: 1,000,000 map of the fault (ITGE, 1995) suggests that the fault has a sub-linear trace with an approximate mean $\mathrm{N} 45^{\circ} \mathrm{E}$ azimuth.

In detail the fault sectors can be divided into shorter segments. This segmentation is based on major lithology changes, the presence of pull-apart and push-up structures, changes in the fault orientation, and the presence of one or more sub-parallel fault traces (Figs. 3 and 4). We consider this segmentation as the maximum possible segmentation associated with surface rupture of the APF 
in the absence of paleoseismic studies along the fault (see below).

The northern, central and southern sectors of the APF comprise three, four and six segments, respectively (Fig. 3). Only the central sector has been mapped with detail in this study and, thus, we consider its segmentation more robust than that of the other two sectors. We have used 1:1,000,000 and 1:50,000 geology maps and published studies (e.g.: Gonçalvez and Torre de Asunção, 1970; Gonçalvez et al., 1972; Cabral, 1995; ITGE, 1995) to define the segments of the other two sectors. In this study we have not assessed segmentation of the offshore part of the fault.

The APF segments, from north to south (Fig 3) are:

\subsection{Northern Sector}

Muñana Segment (42 km long): extends from the Duero Basin margin to Casas del Puerto township. This segment is associated with the western margin of the Amblés Ba$\sin$. While the geomorphic expression shows a relatively linear trend (main azimuth of $\mathrm{N} 58^{\circ} \mathrm{E}$ ), and the dike is very continuous, the actual main fault trace is not clear on the geological maps.

Barco Segment $(26 \mathrm{~km})$ : extends from Casas del Puerto to Barco de Ávila townships. There is a slight change in the fault trend $\left(\mathrm{N} 56^{\circ} \mathrm{E}\right)$ compared to the segment to the north. The basement is homogeneous along its length and the fault is mapped as a single trace. The northern segment boundary around Casas del Puerto is defined by a lithological change in the basement. Also at this location, the presence of Tertiary sediments could be locally associated with a step over of the main trace of the APF.

Jerte Segment (64 km): extends from Barco de Ávila to Plasencia pull-apart basin (Figs. 3 and 4). The fault has a $\mathrm{N} 50^{\circ} \mathrm{E}$ trend, and a very linear trace forming a deeply incised linear valley (Jerte Valley) located in between two high relief area (Sierra de Gredos, SG, and Sierra Candelario, SC; Fig. 5). In the southern end of the segment, the Plasencia pull-apart basin is associated with a change in basement rocks (granitoids to the north and Precambrian slates to the south) (Figs. 3 and 4). This segment could also be divided at Puerto de Tornavacas (Fig. 3) where the geomorphic expression suggests the presence of sediments associated with a left step. Further studies are required to prove the presence of this step-over.

\subsection{Central Sector}

Cañaveral Segment $(43 \mathrm{~km})$ : extends from the Plasencia pull-apart basin to the Cañaveral pull-apart basin. As at the northern segment boundary, the southern end of the pull-apart basin coincides with a change in basement lithologies, with Precambrian slates to the north and granitoids to the south. The fault is located adjacent to an elongated area of positive relief with same trend as the fault. The relief may arise from reverse movement of the Bejar fault (BF in Fig. 3), at the eastern margin of the Coria-Galisteo Basin (Figs. 3 and 4), a fault that is parallel to the APF along this whole segment and located $4-5 \mathrm{~km}$ west of the APF. It is possible that this fault may merge with the APF in depth. The APF comprises a single trace, except at the segment boundaries, and has a mean $\mathrm{N} 50^{\circ} \mathrm{E}$ trend. The total lateral displacement of the fault along this segment is $3 \mathrm{~km}$ from displacements of the Silurian Quartize at Puerto de los Castaños area (Figs. 4 and 6).

Brozas Segment $(27 \mathrm{~km})$ : extends between the Cañaveral to the Ribera de Araya pull-apart basins. The Ribera de Araya pull-apart basin also coincides with a change from granitoids to the north to Precambrian slates to the south (Fig. 4). The APF comprises a single trace, except at the segment boundaries, and has a mean $\mathrm{N} 50^{\circ} \mathrm{E}$ trend. The total displacement of the fault along this segment is $2.5 \mathrm{~km}$ from displacement of the boundaries of the Cabeza de Araya Batholith (Fig. 4).

Aliseda Segment $(34 \mathrm{~km})$ : extends from the Ribera de Araya to the Albarragena pull-apart basins. Again, the fault segment extends along uniform basement formations of slates and quartzites and the boundary with granitic batholites is located at the pull-apart basins (Fig. 4). The main fault azimuth is $\mathrm{N} 30^{\circ} \mathrm{E}$ and the trace is very linear. The total displacement of the fault along this segment is $1.5 \mathrm{~km}$ from displacements of the Silurian Quartize at Sierra de San Pedro area (Figs. 4 and 6).

Alburquerque Segment $(20 \mathrm{~km})$ : extends from the Albarragena pull-apart basins to the northern margin of the Guadiana Basin (Fig. 3). The fault trend and linear trace are very similar to the previous segment but the total displacement of the fault along this segment is $3 \mathrm{~km}$ from displacement of the boundaries of Alburquerque Batholith (Fig. 4). The fault azimuth is mainly N35 ${ }^{\circ} \mathrm{E}$ (Fig. 4).

\subsection{Southern Sector}

Campomaior segment $(22 \mathrm{~km})$ : extends from the northern margin of Guadiana Basin to a $4 \mathrm{~km}$ wide left step that lies just south of Caia River (CR in Fig. 3). Bedrock lithology along this segment consist mainly of meta-sedimentary formations which are bounded to the north and south by granitoids. The main fault azimuth is $\mathrm{N} 38^{\circ} \mathrm{E}$. Total lateral displacement along the segment is of about 4 $\mathrm{km}$ at its midpoint and decreases northwards to $3 \mathrm{~km}$ and southwards to $1 \mathrm{~km}$. Along this segment and the segment to the south, there is a significant vertical fault displace- 


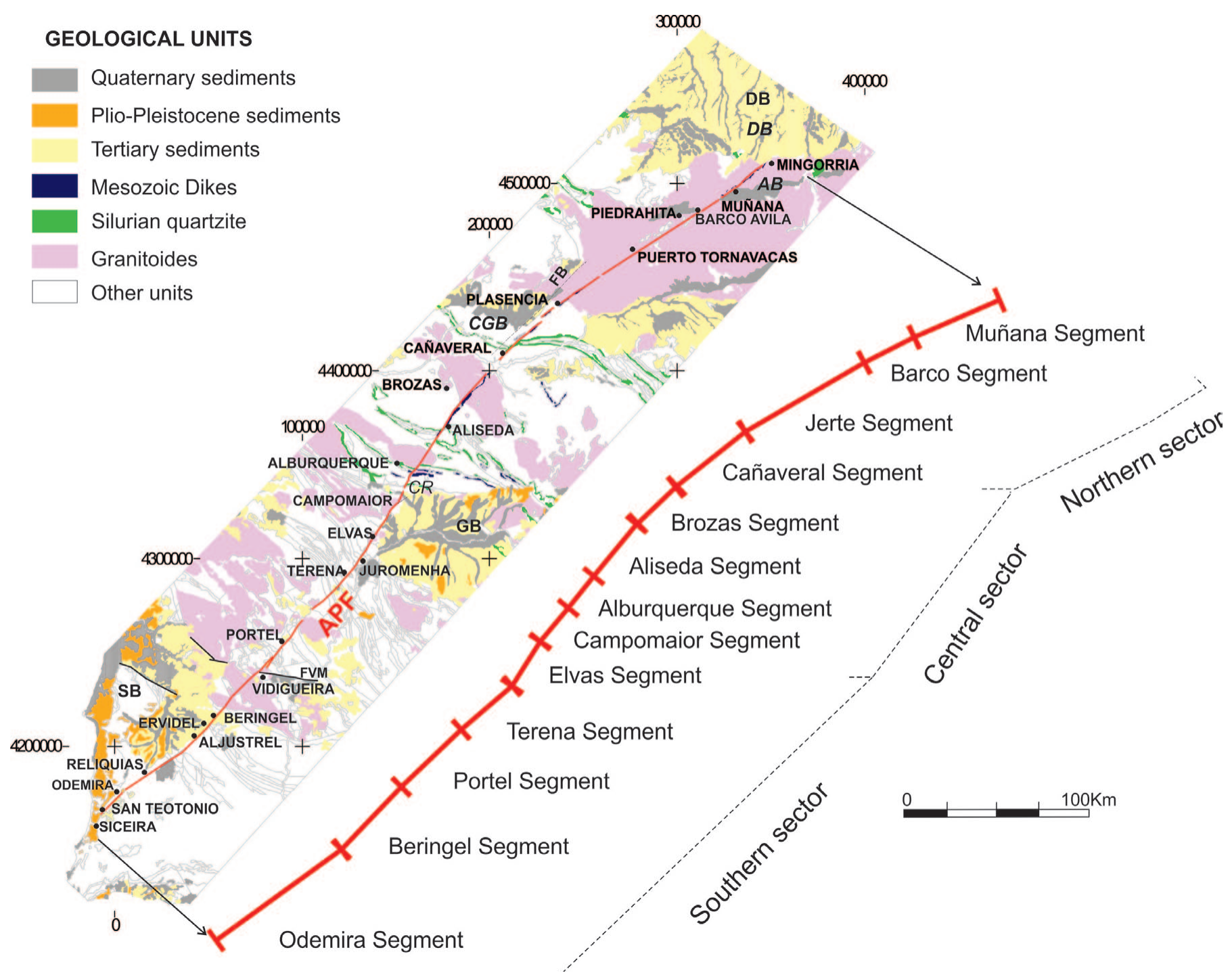

Fig. 3.- General geological map along the Alentejo-Plasencia fault (ITGE, 1995) and segmentation model of the fault. APF, Alentejo-Plasencia Fault; BF, Bejar Fault; VMF, Vidigueira-Moura Fault; DB, Duero Basin; AB, Ambles Basin; CGB, Coria-Galisteo Basin; GB, Guadiana Basin; SB, Sado Basin; CR, Caia River.

Fig. 3.- Mapa geológico general a lo largo de la falla Alentejo-Plasencia (ITGE, 1995) y modelo de segmentación de la falla. APF, falla de Alentejo-Plasencia; BF, falla de Bejar; VMF, falla de Vidigueira-Moura. DB, cuenca del Duero, AB; cuenca de Ambles; CGB, cuenca de Coria-Galisteo; GB, cuenca del Guadiana; SB, cuenca de Sado. CR, río Caia.

ment component.

Elvás segment $(28 \mathrm{~km})$ : extends from the left step close Caia River to Juromehna township. The fault azimuth is slighltly more easterly than the segment to the north $\left(\mathrm{N} 38-40^{\circ} \mathrm{E}\right)$, particularly at its southern end.

Terena segment $(33 \mathrm{~km})$ : extends from Juromehna to Falcoeiras. At the southern end the fault segment there is a left step where Tertiary sediments outcrop. This may indicate the presence of a pull-apart basin. The fault azimuth is principally $\mathrm{N} 48^{\circ} \mathrm{E}$.

Portel segment $(41 \mathrm{~km})$ : extends from the small sedimentary basin at the left step of Falcoeiras to the intersection with the Vidigueira-Moura Fault, where the APF splays into two strands and forms a small sedimentary basin.

Beringel segment $(44 \mathrm{~km})$ : extends from the intersection with the Vidigueira-Moura Fault to Ervidel township. Fault traces of this segment and the segment to the south form the southeastern boundary of the Sado Basin. This segment trends $\mathrm{N} 43-50^{\circ} \mathrm{E}$.

Odemira segment $(75 \mathrm{~km})$ : extends from Odemira township to the coast. The fault has a trend of $\mathrm{N} 45^{\circ} \mathrm{E}$ at the northern end which changes to a more southerly trend at the southern end $\left(\mathrm{N} 15^{\circ} \mathrm{E}\right)$. The fault branches into several strands parallel to the coast. This segment is longer than others and it is possible that more detailed study would reveal the possibility of two or more segments in this area. Here, we present the simplest model. 


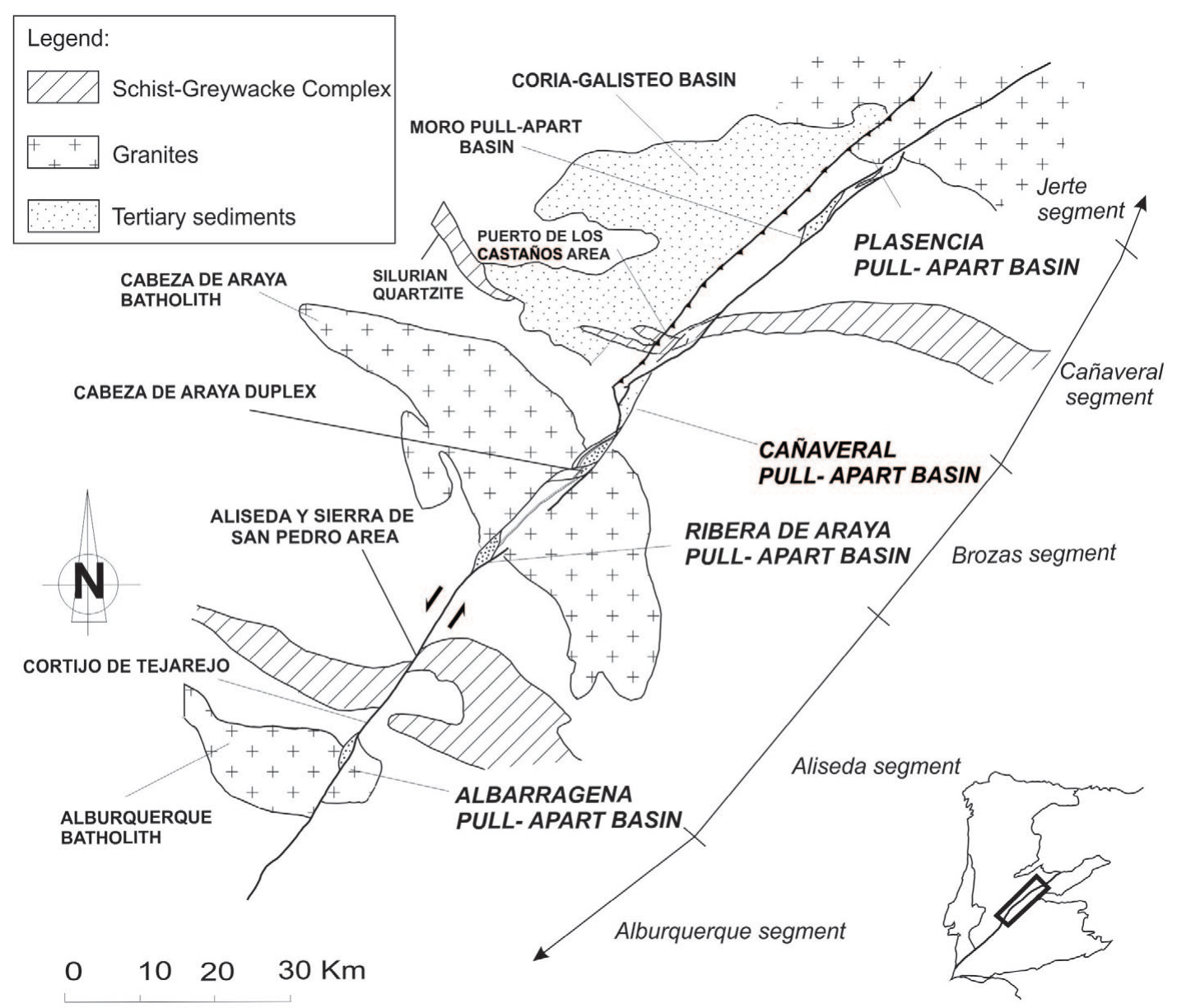

Fig. 4.- Location of the pull-apart basins and other points of interest along the Alentejo-Plasencia fault .

Fig. 4.- Localización de las cuencas pull-apart y otros puntos de interés a lo largo de la falla Alentejo-Plasencia.

\section{Evidence for current tectonic activity of the Alentejo-Plasencia fault}

In this study, we define active faults as faults that have moved within the "current tectonic regime" (Muir-Wood and Mallard, 1992). The current tectonic regime is the period in which the tectonic stresses have remained constant (stress axis orientation and type of tectonic regime) and deformation can be assumed to be constant. Some authors described the beginning of the "Neotectonic period" for the Iberian Peninsula as the boundary between Middle and late Miocene (at 11-12 Ma) when the collision with Africa was established (Baena et al., 1991). Other authors consider it starts at the end of the Pliocene $(\sim 2 \mathrm{Ma})$ when a NE trending contractional phase was established following a phase of tectonic quiescence associated with E-W extension at the Gibraltar arc (Cabral, 1995).

For the central-western part of the Iberian Peninsula we accept that the current tectonic regime started during the Middle Miocene (Dewey et al., 1989; Srivastava et al., 1990; Andeweg, 2002), whereas in southern Iberia the tectonic evolution may suggest a more recent start of the current tectonic regime. This late stage southern perturbation is not clearly displayed in the study area. In the interior of the Iberian Peninsula, the sedimentary record and tectonic deformation also suggest no major changes since the onset of the collision of Iberia and Africa (Guadarrama Stage of Capote et al., 2002; see section $2)$. This suggests the changes in plate boundary stresses are largely attenuated by the time they are felt in the intraplate region, and that the rates of deformation will be low but probably constant over long periods of time.

The current activity of the APF is evidenced by displacement of Tertiary-Quaternary sediments and by displacement of geomorphic surfaces formed within the current tectonic regime. In the next sections, we will describe in detail the field observations from the region studied (Cañaveral, Brozas, Aliseda and Alburquerque segments, corresponding to the Central Sector of the fault; Fig. 3) that illustrate the current tectonic active of the APF. 


\subsection{Total displacement of the APF}

The total displacement of the fault provides a minimum estimate of the slip rate in the current tectonic regime, and an indication of the horizontal to vertical displacement ratio. In the study area, the total lateral displacement of Precambrian to Silurian bedrock units ranges from 1.3 to $3.6 \mathrm{~km}$ if displacements are only derived from displacements along the main trace (Rincón et al., 2000; Villamor 2002) (Table 1). These measurements could be up to $6 \mathrm{~km}$ if drag folding in a width of at least $10 \mathrm{~km}$ is taken into the measurements (González Flores, 1996; see drag folding of Silurian Quartzite synclines in Figs. 4 and 6). For segments of the fault south of this study, the values we obtain using regional geological mapping range from 3 to $3.5 \mathrm{~km}$ (Santos García and Casas Ruíz, 1982; Gonçalez and Torre Assunçao, 1970).

The horizontal to vertical displacement ratio was obtained from measuring lateral and vertical displacements of the Silurian Quartzite synclines at two locations, Puerto de los Castaños and Sierra de San Pedro (Figs. 4 and 6; Table 1; for more detail see Villamor, 2002). The vertical values obtained are $80 \pm 20 \mathrm{~m}$ (Fig. 6) and $75 \pm 20 \mathrm{~m}$, respectively. The preferred total horizontal displacements at these locations are $3.2 \pm 0.1$ and $1.1 \pm 0.05 \mathrm{~km}$, respectively. These are used to obtain horizontal to vertical displacement ratios of 40:1 and 15:1, respectively.

\subsection{APF displacements of sediments deposited within the current tectonic regime (from Middle Miocene to present)}

Tertiary formations in the study area are all terrigeneous continental sediments. These sediments are transported by alluvial fans in arid or semiarid conditions, as a response to tectonic uplift. Sediments associated with the APF are mainly related to the relief created at the edges of the pull-apart basins and sediment preservation is due to basin subsidence (Figs. 7 and 8a). In the wider area around the study area, fossil records have only been found at one location in the Plasencia pull-apart basin. Therefore, the ages assigned to the sediments in this study are based on published sedimentary correlations among the Ciudad Rodrigo (Martín-Serrano, 1991b), southwestern Duero (Santisteban et al., 1991), and the Plasencia pullapart basin.

The main sedimentary sequences in the area are divided into the Paleogene (divided into Paleocene and EoceneOligocene Units) and Neogene sediments (divided into the Early-Middle Miocene series and the Middle-Upper Miocene series, also known as red and ochre Neogene series, respectively). The fossils found in the Plasencia pull-apart basin belong to the red Neogene series (fossils were dated early to middle Miocene; Hernández-Pacheco and Crusafont Pairo, 1960). A Plio-Quaternary alluvial fan sedimentary unit called Raña is also used here to assess timing of fault movement. This unit is described as the last stages of the ochre Neogene series by some authors, while others consider it a new sedimentary stage of early Quaternary age (see discussions in Cabral, 1995; Villamor, 2002 and references therein). Post-Raña sediments are associated with alluvial fans and terraces. A detailed description of the sedimentary units in association with the APF in the study area, and correlation among basins is presented in Villamor (2002).

We consider that the sediments associated with the current tectonic regime in this region are Neogene sediments and younger, that is, sediments deposited since the red Neogene series. Therefore, deformation of those sediments strongly suggests the faults of the APF have been active within the current tectonic regime.

The red and ochre Neogene series (hereafter called red and ochre series) along the APF are found within the pullapart basins (Figs. 7 and 8). These sediments represent proximal alluvial fan deposits associated with the basin margin faults. In the Plasencia pull-apart basin (Fig. 7), for example, gravelly ochre sediments (with a strong weathering dominated by kaolinite) are found overlying clayey red sediments (where Early to Middle Miocene fossils were reported by Hernández-Pacheco and Crusafont Pairo, 1960) at the eastern basin- bounding fault. Both series are sourced from Precambrian Slates rounding the basin (Fig. 8a). The sediments are tilted back towards the fault indicating fault movement after deposition (Fig. 8b).

In the Cañaveral pull-apart basin (Fig. 7), three distinctive types of sediments fill the basin. From top to bottom they are: gravel-dominated ochre series sediments sourced from Precambrian Slates rounding the basin; gravel-dominated red series sediments, also sourced from Precambrian Slates rounding the basin and separated from the overlying sediments by an angular unconformity; and sand-dominated Eocene-Oligocene sediments sourced from distant granitoides (Fig. 8e). The sedimentary facies displayed by these sediments suggest that while the Neogene series (red and ochre sediments) are proximal sediments associated with movement of the boundary faults, the Eocene-Oligocene deposits were distal, pre-existing sediments that have been preserved by subsidence of the pull-apart basin. In the Cañaveral basin, the ochre series are clearly faulted in a reverse fashion against the Eocene-Oligocene deposits along secondary faults at the northwest end of the basin (Fig. 8d), and in a normal fash- 
Fig. 5.- Digital elevation model (SGE, 1997) showing the geomorphic expression of the Alentejo-Plasencia fault (APF). The northern sector crosses the Central Ranges of Spain while the central and southern sector of the fault cross the Meseta. APF, Alentejo-Plasencia Fault; SCMS, Spanish Central Mountainous System; EM, Extremadura Meseta; SG, Sierra de Gredos; SC, Sierra de Candelario.

Fig. 5.- Modelo digital del terreno (SGE, 1997) mostrando la expression geomorfológica de la falla Alentejo-Plasencia (APF). El sector norte cruza las sierras del Sistema Central Español mientras que los sectores central y meridional de la falla cruzan la Meseta. APF, falla Alentejo-Plasencia; SCMS, Sistema Central Español; EM, Meseta extremeña Meseta; SG , Sierra de Gredos; $\mathrm{SC}$, Sierra de Candelario.

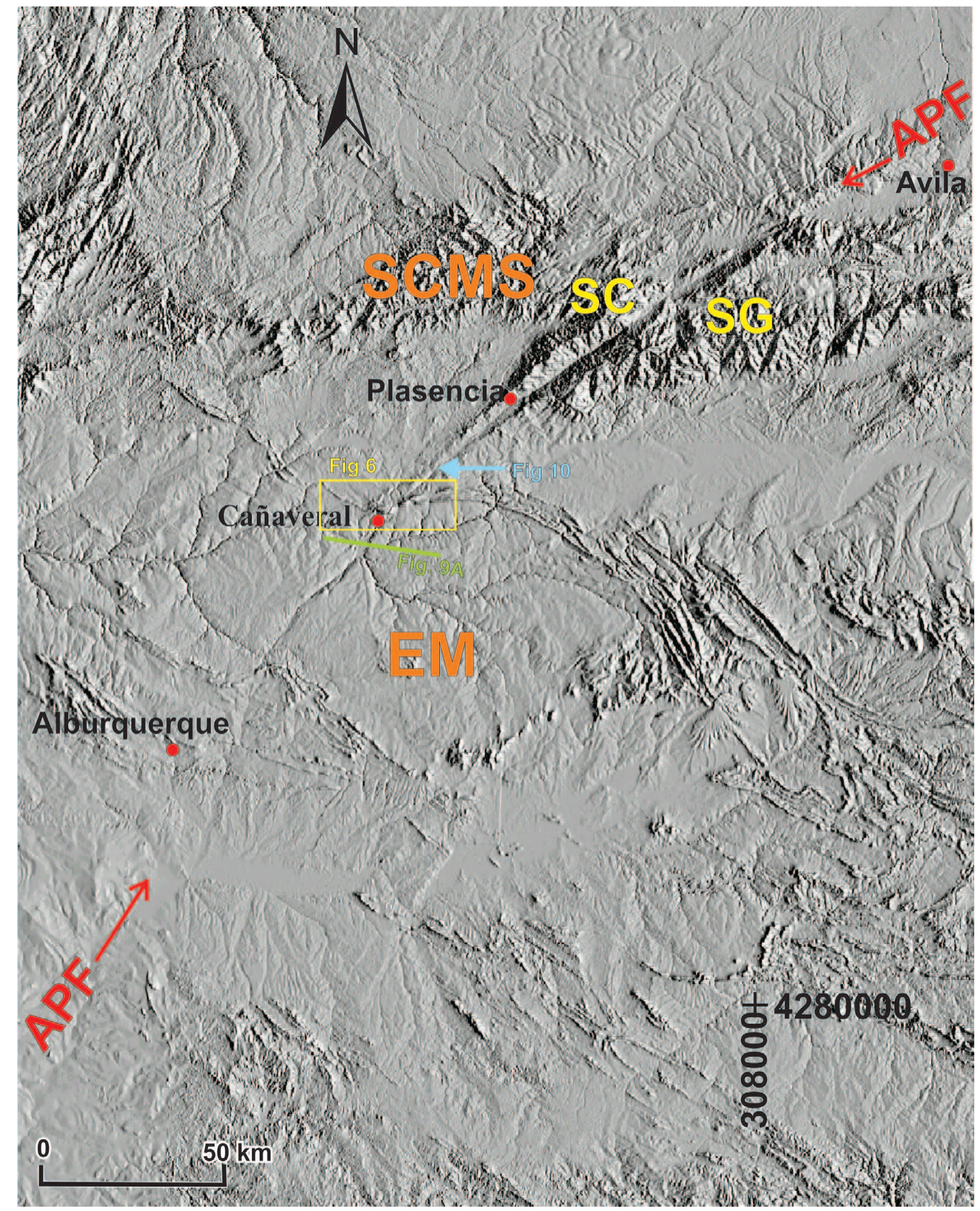

ion against Precambrian slates along the western boundary fault. Also, at the eastern margin all three units are tilted back towards the eastern fault in a similar fashion to the sediments at the Plasencia pull-apart basin eastern margin. Along the eastern boundary fault of the Cañaveral basin a Middle Pleistocene fluvial terrace is faulted (Fig. 8c).

Neogene series sediments are also found at Moro and Ribera de Araya pull-apart basins but the detailed relationships with faulting are not exposed (Fig. 4). In the Albarragena pull-apart basin (Fig. 4), deposits that are either Early Pleistocene (Villamor, 2002) or Neogene-Pliocene (age is from N. Pimentel pers. comm.), are clearly faulted (Fig. 8f).
4.3. APF displacements of geomorphic surfaces formed within the current tectonic regime

We have used models of the evolution of the geomorphic surfaces for the wider central and western Spain area (García-Abad and Martin-Serrano, 1980; Molina et al., 1985; Fernández Macarro and Blanco Sánchez, 1990; Martin-Serrano, 1991a; 1991b; 1994) to assign ages to the surfaces displaced by the APF in our study area. The model of geomorphic evolution for the central western Spain assigns ages to geomorphic surfaces based on presence of Tertiary and Quaternary sediments and properties of weathering mantles on bedrock associated with them. A detailed discussion of these models can be 


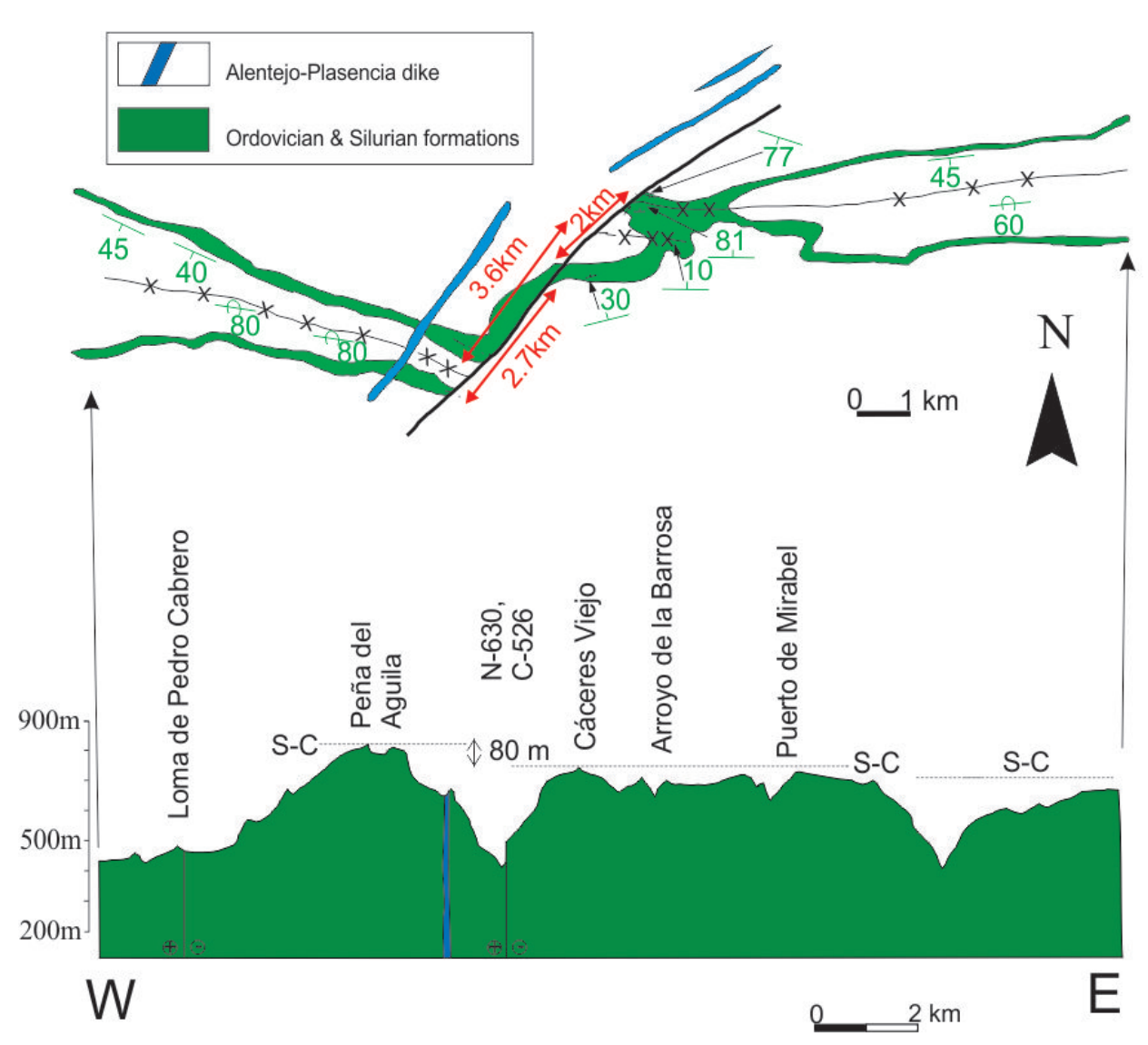

Fig. 6.- Total horizontal and vertical displacements of the Alentejo-Plasencia fault. Upper figure shows map view of the Silurian quartzite syncline (Puerto de los Castaños area) and possible total left lateral offsets. Lower figure shows a topographic profile along the northern flank of the syncline to assess vertical offset. Information was obtained for 1:50,000 maps (Martín Herrero, 1987b; Bascones Alvira and Martín Herrero,1987). For location see Figure 5.

Fig. 6.- Desplazamientos horizontal y vertical totales de la falla Alentejo-Plasencia. La figura superior muestra una visión en mapa del sinclinal de cuarcita del Silúrico (sector de Puerto de los Castaños) y posibles desplazamientos de desgarre lateral-izquierdo. La figura inferior muestra un perfil topográfico a lo largo del flanco norte del sinclinal con el fin de estimar el desplazamiento vertical. La información fue obtenida a partir de mapas 1:50,000 mapas (Martín Herrero et al., 1987b; Bascones-Alvira y Martín-Herrero,1987).Ver Figure 5 para localización. found in Villamor (2002). A description of sediments and weathering mantles in this area is presented by Tsige et al. (1997). For the Quaternary surfaces we have used the ages assigned to terraces of different altitudes above the Tagus and Guadiana Rivers (Ugidos Meana et al., 1987a; 1987b; 1988; Pérez-González et al., 1989).

Of the surfaces defined for the study area (Tsige et al., 1997; Villamor, 2002), the following are relevant to assess the current activity of the APF (Fig. 9):

S-Bas (superficie sobre basamento): is the extensive geomorphic surface in the Extremadura Meseta. This surface represents the exposed unweathered basement after the weathering mantle has been stripped. The exact age is difficult to assign and the surface is likely to be diachronous in age. However, clay mineralogy studies of the area close to the APF (Tsige et al., 1997) suggest that the oldest age of the weathering mantle is correlative to the red Neogene series (Early to Middle Miocene; with dominant smectitite over illite and kaolinite) of the Duero Basin (described above).

S-Raña (superficie sobre raña): is the paleo-ground surface above the Raña sediments. The Raña deposits have intense and characteristic weathering. Its fine grained components have been fully weathered to clays (illite and kaolinite) and the coarse grained are mainly, and almost exclusively, very rounded gravel (occasionally blocks) of quartzite. There are two levels of Raña deposits. The upper one, S- Raña 1 (S-R1 in Fig. 9a) lays conformably over a well-developed weathering mantle. This mantle is a smectite-rich mantle and becomes kaolinite-rich at the top suggesting superposition of the Middle to Upper Miocene weathering (coeval with depositions of the kaolinite-rich ochre Neogene sedimentary series), over the early to middle Miocene weathering (coeval with depositions of the smectite-rich red Neogene sedimentary series). The lower Raña surface, S-Raña $2(\sim 50 \mathrm{~m}$ below the upper one), is erosional onto the weathering mantle.

Vertical displacements of the S-Bas surface are more obvious at the Plasencia, Moro and Cañaveral pull-apart basins (Fig. 9a) where the basin subsidence is large compared with vertical displacements along other sections of the fault. Analysis of the geomorphic surfaces combined with gravity modelling used to assess basin thickness suggest that the subsidence of the S-Bas surface at the pull-apart basins is of the order of 160 to $300 \mathrm{~m}$ (Fig. 9b; Villamor, 2002). These values can be converted to horizontal displacements if we use results from numerical modelling studies where subsidence in pull-apart basins is related to the amount of total lateral displacement (Rodgers, 1980). That study suggests that subsidence represents 15 to $25 \%$ of lateral displacement. Thus, horizontal displacement on the fault of 0.8 to $2 \mathrm{~km}$ are 
implied since formation of the pull-apart basins.

Vertical displacements of the surface S-Raña of $\sim 2 \mathrm{~m}$ has been found north of Ribera de Albarragena (location shown on Fig. 4). This value can be converted to horizontal displacement using the horizontal to vertical ratio estimated from displacement of older chronological markers (section 4.1; Table 1). The estimated horizontal displacement value associated with the S-Raña is 20 to $100 \mathrm{~m}$ if we use both ratios shown on Table 1 .

\section{Preliminary characterisation of the earthquake potential of the APF: fault slip rate, magnitude and recurrence interval}

\subsection{Fault slip rate of the $A P F$}

Fault slip rate estimates for the APF presented here are not well constrained, but are the best available. Most of the displacement measurements are from older reference

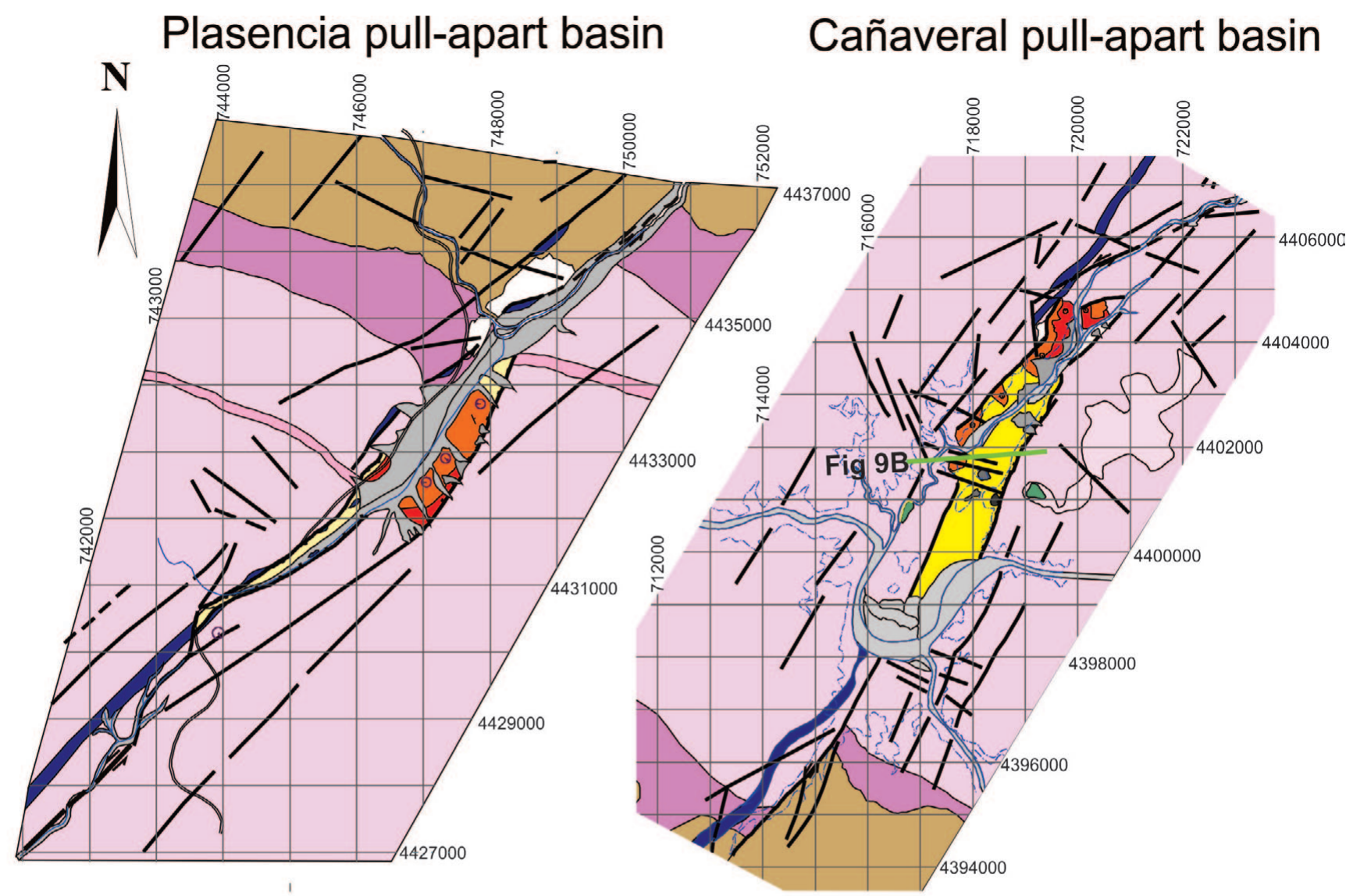

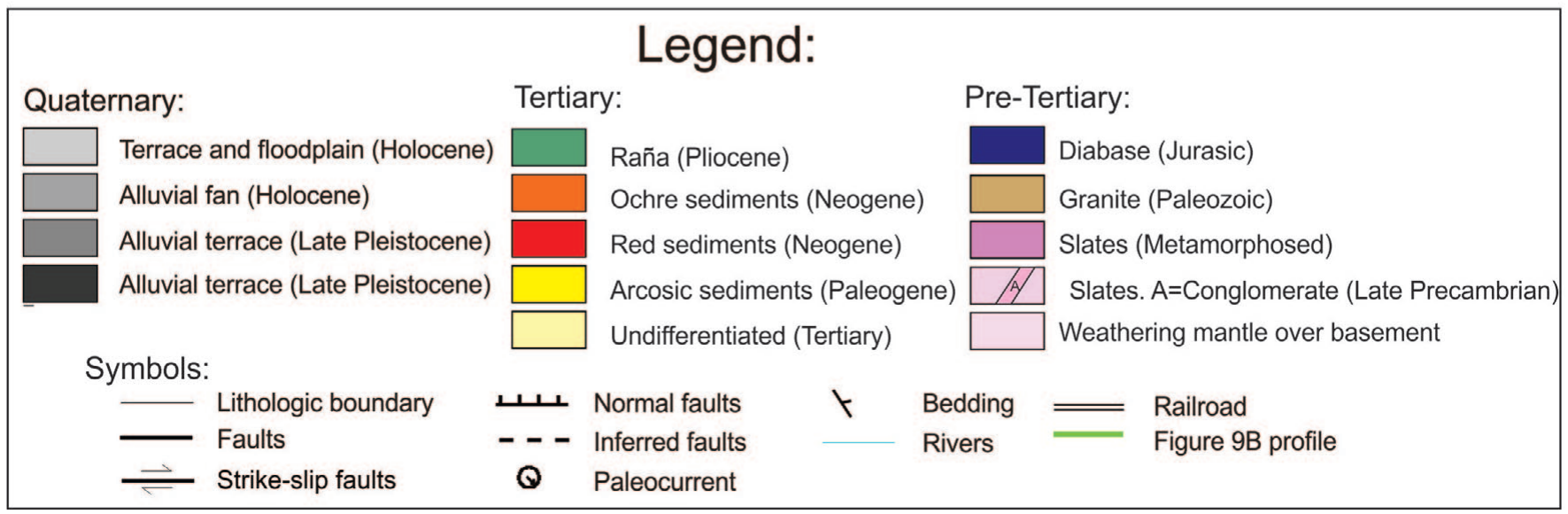

Fig. 7.- Geological maps of the Plasencia and Cañaveral pull-apart basins. Maps produced in this study at 1:25.000 scale from review of aerial photos and existing maps (Martín Herrero et al., 1987a; 1987b; Ugidos Meana et al. 1987), and field reconnaissance.

Fig. 7.- Mapas geológicos de las cuencas pull-apart de Plasencia y Cañaveral. Mapas generado sen éste estudio a escala 1:25.000 a partir de la revisión de fotografías aéreas, cartografías previas (Herrero et al., 1987a; 1987b; Ugidos-Meana et al. 1987), y reconocimientos de campo. 

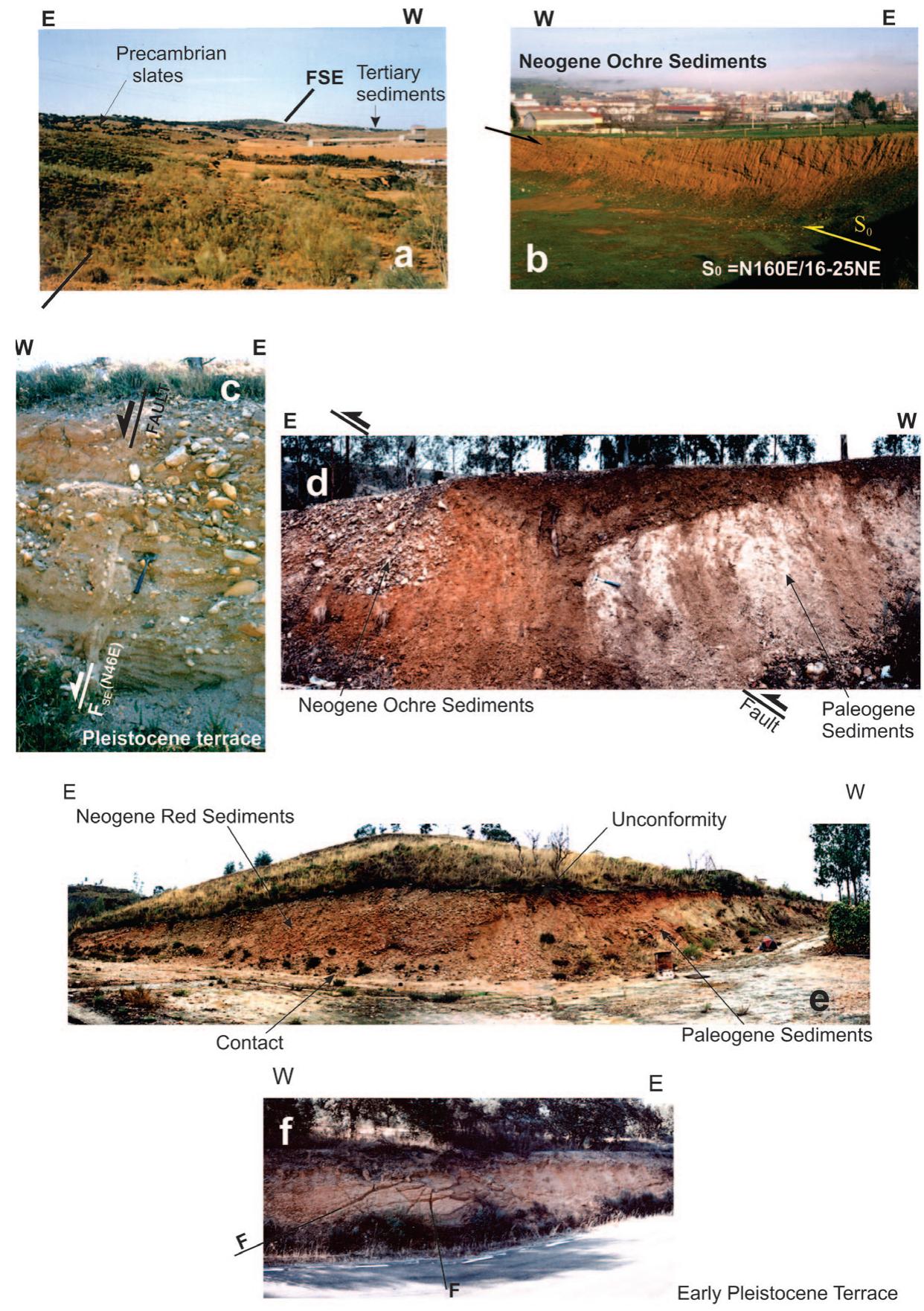

Early Pleistocene Terrace
Fig. 8.- A) Photograph of the normal fault contact between basement and Tertiary sediments at the eastern border of the Plasencia pull-apart basin. B) Neogene sediments of the Plasencia pull-apart basin are tilted towards the eastern normal fault. C) Deformed Middle Pleistocene fluvial terrace on the eastern normal fault of the Cañaveral pull-apart basin. Displacement across fault is $>1 \mathrm{~m}$. D) Paleogene sediments thrusted over Neogene sediments along a secondary reverse fault on the NW part of the Cañaveral pull-apart basin (Local road to Coria township). E) Paleogene to Neogene sedimentary sequence in the Cañaveral pull-apart basin. Neogene sediments lay unconformably over Paleogene sediments. All sediments in the photograph are tilted towards the eastern margin fault of the basin. F) Fractured Early Pleistocene fluvial terrace. For locations of Figs. 8a to 8e, see Fig. 7. For location of Fig. 8f, see Fig. 5.

Fig. 8.- A) Fotografía del contacto por falla normal entre el basamento y los sedimentos terciarios en el borde este de la cuenca pull-apart de Plasencia. B) Los sedimentos neógenos de la cuenca pull-apart de Plasencia se encuentran basculados hacia la falla normal oriental. C) Terraza fluvial del Pleistoceno Medio deformada en la falla normal oriental de la cuenca pull-apart de Cañaveral. El desplazamiento en la falla es $>1 \mathrm{~m}$. D) Sedimentos paleógenos afectados dispuestos sobre sedimentos neógenos mediante una falla inversa secundaria en el sector NO de la cuenca pull-apart de Cañaveral. (carretera local a la ciudad de Coria). E) Secuencia sedimentaria paleógena a neógena en la cuenca pull-apart de Cañaveral. Los sedimentos neógenos se disponen discordantes sobre sedimentos paleógenos. Todos los sedimentos en la fotografía están basculados hacia la falla marginal oriental de la cuenca. F). Terraza del Pleistoceno Inferior fracturada. Ver Fig. 7 para localización Figs. 8a a 8e. Para localización de Fig. 8f, ver Fig. 5. horizons and the age associated with those displacements has large uncertainties. Recent (Quaternary) fault displacements are difficult to find along the APF and only vertical displacements could be measured. The transformations from vertical to net displacements (based on horizontal to vertical ratios obtained from total fault displacements or from other transformations described above) implemented here carry great uncertainties.

Slip rates have been obtained from three sources: the total displacements (e.g. Fig. 6), displacements since the initiation of pull-apart basins (e.g. Fig. 9), and the dis- placements of the geomorphic surface associated with Raña deposits calculated above (Table 1). To obtain the slip rate associated with total displacements, we have used a range of ages for the initiation of movement along the APF. Fault initiation time is debatable but it has been suggested that it took place either during the Oligocene to Early Miocene (as early as $35 \mathrm{Ma}$; Villamor, 2002) or coincident with the initiation of the pull-apart basin during Early to Middle Miocene (as early as 16 Ma ago; Villamor et al., 2004). We obtain values of 0.03 to $0.2 \mathrm{~mm} /$ yr from these calculations (Table 1). These estimates are 

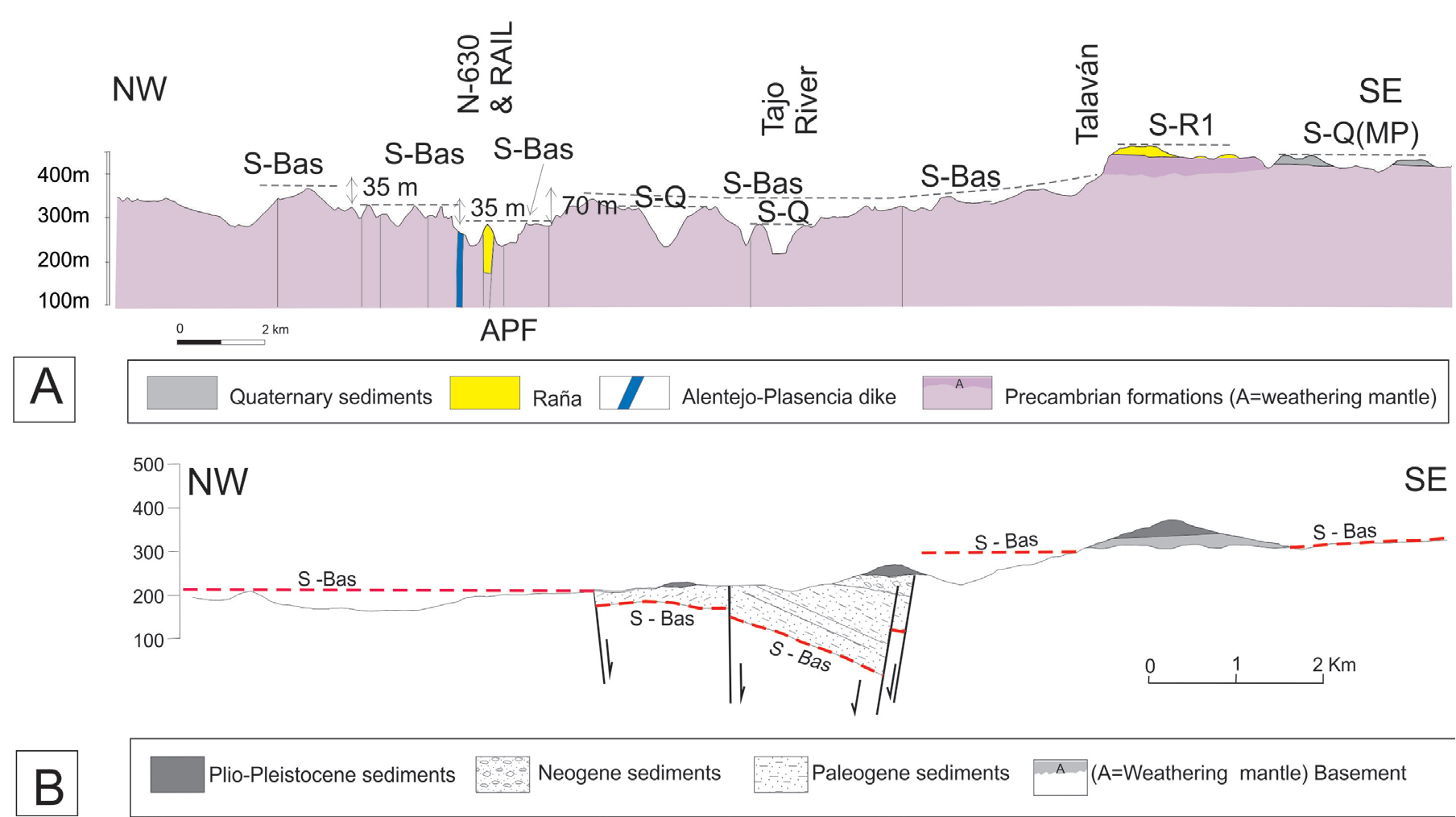

Fig. 9.- A) Regional geological cross-sections north of Cañaveral pull-apart basin (see location on Figure 5; cross-section is based on Martín Herrero et al., 1987b). See text for description of geomorphic surfaces (S-Bas, S-R1and S-Q).B) Detail geological cross-section of the Cañaveral pull-apart basin see location on Figures 5 and 7).

Fig. 9.- A) Cortes geológicos regionales al norte de la Cuenca pull-apart de Cañaveral (ver localización en figura 5; el corte está basado en Martín-Herrero et al., 1987b). Ver texto para la descripción de las superficies geomorfológicas (S-Bas, S-R1and S-Q). B) Corte geológico de detalle de la Cuenca pull-apart de Cañaveral, ver localización en figuras 5 y 7).

preliminary and the assumption of constant slip rate may not be realistic in this intraplate setting. However, these values do provide a basis for considering earthquake hazard. The slip rate values do agree in general terms with the subtle geomorphic expression of current activity described above and are coherent with slip rates from other similar faults in the Iberian Massif (see below).

Our best estimates of slip rate of makers of recent age (within the current tectonic regime) are 0.01 to $0.1 \mathrm{~mm} /$ yr (simplified from values on Table 1). For the slip rate values associated with the initiation of the pull-apart basins we use $\sim 16$ Ma years (pull-apart basin initiation; Villamor et al., 2004). Those values are 0.05 to $0.1 \mathrm{~mm} /$ yr (Table 1), which are also in agreement with slip rate values of $0.3-0.5 \mathrm{~mm} / \mathrm{yr}$ in similar NE trending strikeslip faults in the Iberian Massif from paleoseismic studies (Rockwell et al., 2009). For slip rates associated with the S-Raña surface, we use a range of ages from 5 to $2 \mathrm{Ma}$ for the Raña sediments (based on different authors, see discussion in Villamor, 2002 and section 4). For the SRaña we obtain slip rate values from 0.004 to $0.05 \mathrm{~mm} / \mathrm{yr}$ if we take into account values obtained using 5 and $2 \mathrm{Ma}$ as the Raña age. We consider that ages of 2 Ma may be more representative than $5 \mathrm{Ma}$ for the end of the deposition of the Raña deposits because, despite the diachronic character of the deposit, to date, the only age available age for the Raña is close to $2 \mathrm{Ma}(\sim 1.7 \mathrm{Ma}$; Baena and Díaz, 1997). We thus propose the $\sim 0.01 \mathrm{~mm} / \mathrm{yr}$ slip rate as a best-estimate lower slip rate for the fault.

Low to very low fault slip rates for the APF in the range from 0.001 to $0.1 \mathrm{~mm} / \mathrm{yr}$ are supported by only rare observations of recent geomorphic lateral offsets (typical of active strike-slip faults). From the aerial photo review and analysis of DEMs for the Cañaveral, Brozas, Aliseda y Alburquerque segments we could only identify a possible recent fault scarp and a shutter ridge close to the Moro pull-apart basin (Fig. 10). Our results are also in agreement with slip rates obtained for the southern sector of the fault (0.056 to $0.07 \mathrm{~mm} / \mathrm{yr}$; Cabral, 1995).

\subsection{Earthquake magnitudes associated with the APF}

Earthquake magnitudes estimated for rupture of the APF range from $\mathrm{M}_{\mathrm{w}} 6.6$ to 8.7 (Fig. 11; Table 2; Appen- 


\begin{tabular}{|c|c|c|c|c|c|c|c|}
\hline \multirow[t]{2}{*}{ Location } & \multicolumn{3}{|c|}{$\begin{array}{l}\text { Horizontal displacement }(\mathbf{k m}) / \\
\text { vertical displacement }(\mathbf{k m})\end{array}$} & \multicolumn{3}{|c|}{ Slip rate $(\mathbf{m m} / \mathbf{y r})$} & \multirow[t]{2}{*}{$\begin{array}{c}\text { Horiz: } \\
\text { vert }^{+}\end{array}$} \\
\hline & Total & $\begin{array}{c}\text { Associated } \\
\text { with pull-apart } \\
\text { formation }\end{array}$ & $\begin{array}{c}\text { Associated } \\
\text { with Raña } \\
\text { surface }\end{array}$ & $\begin{array}{c}\text { Total } \\
\text { (for 35 Ma/ } \\
16 \mathrm{Ma} \text { ) }\end{array}$ & $\begin{array}{c}\text { Associated } \\
\text { with pull-apart } \\
\text { formation } \\
(16 \mathrm{Ma}) \\
\end{array}$ & 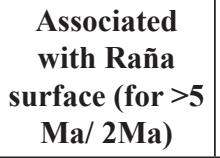 & \\
\hline Plasencia & $\begin{array}{c}3.30 \pm 0.35 / \\
-\end{array}$ & $\begin{array}{l}1.20 \pm 0.40^{* /} \\
0.20 \pm 0.03\end{array}$ & & $\begin{array}{l}0.09 \pm 0.01 / \\
0.20 \pm 0.02^{\mathrm{H}}\end{array}$ & $0.07 \pm 0.02^{\mathrm{N}}$ & & \\
\hline Moro & $\begin{array}{c}3.30 \pm 0.35 / \\
-\end{array}$ & $\begin{array}{l}1.20 \pm 0.40 * / \\
0.20 \pm 0.04\end{array}$ & & $\begin{array}{l}0.09 \pm 0.01 / \\
0.20 \pm 0.02^{\mathrm{H}}\end{array}$ & $0.07 \pm 0.02^{\mathrm{N}}$ & & \\
\hline Puerto Castaños & $\begin{array}{l}3.2 \pm 0.10 / \\
0.08 \pm 0.02\end{array}$ & - & & $\begin{array}{c}0.09 \pm 0.002 / \\
0.20 \pm 0.01^{\mathrm{N}}\end{array}$ & & & $40: 1$ \\
\hline Cañaveral & $\begin{array}{c}2.2 \pm 0.10 / \\
-\end{array}$ & $\begin{array}{l}1.5 \pm 0.50 * / \\
0.25 \pm 0.05\end{array}$ & & $\begin{array}{c}0.06 \pm 0.002 / \\
0.10 \pm 0.01\end{array}$ & $0.09 \pm 0.03^{\mathrm{N}}$ & & \\
\hline Cabeza Araya & $\begin{array}{c}2.40 \pm 0.25 / \\
-\end{array}$ & - & & $\begin{array}{l}0.07 \pm 0.01 / \\
0.10 \pm 0.01^{\mathrm{H}}\end{array}$ & & & \\
\hline Ribera Araya & $\begin{array}{c}1.60 \pm 0.45 / \\
-\end{array}$ & - & & $\begin{array}{c}0.04 \pm 0.01 / \\
0.10 \pm 0.003^{\mathrm{N}}\end{array}$ & & & \\
\hline Aliseda & $\begin{array}{l}1.10 \pm 0.05 / \\
0.075 \pm 0.02\end{array}$ & - & & $\begin{array}{l}0.03 \pm 0.002 / \\
0.07 \pm 0.005^{\mathrm{H}}\end{array}$ & & & $15: 1$ \\
\hline $\begin{array}{l}\text { Ribera } \\
\text { Albarragena }\end{array}$ & $\begin{array}{c}1.3 \pm 0.20 / \\
-\end{array}$ & - & $\begin{array}{l}0.06 \pm 0.04 * * / \\
0.002 \pm 0.001\end{array}$ & $\begin{array}{c}0.04 \pm 0.01 / \\
0.08 \pm 0.01^{\mathrm{H}}\end{array}$ & & $\begin{array}{c}0.012 \pm 0.008 / \\
0.03 \pm 0.02^{\mathrm{N}}\end{array}$ & \\
\hline
\end{tabular}

* Derived from vertical displacement using Rodgers (1980); ** Derived from vertical displacement using mean results from horizontal to vertical ratios on last column; ${ }^{+}$Horizontal to vertical ratio; only calculated where both values are obtained independently; ${ }^{N}$ Net slip rate; ${ }^{H}$ Horizontal slip rate

Table 1.- Displacement and slip rate values associated with the APF

Tabla 1.- Desplacemiento and tasa de deslizamiento associados a la FAP

dix 1). These magnitudes have been estimated using empirical scaling relationships of magnitude as a function of fault length and fault area (Wells and Coppersmith, 1994; Anderson et al., 1996; Berryman et al., 2001; and Stirling et al., 2002). Potential rupture length has been assigned from fault geometry and the fault has been divided into possible fault segments (Fig. 3; Table 2). This segmentation represents the smallest possible surface ruptures of the APF based on our mapping. These will produce magnitudes between $M_{w} 6.6$ and 7.6 (Table 2). Because we do not have appropriate paleoseismic data to confirm whether the fault always ruptures in small segments or in multiple segments, we have also assumed that it can rupture 2 segments or more, up to the whole fault, i.e., minimum segmentation (Table 2). This assumption implies that the maximum magnitude associated with the APF, for a non-segmented rupture model of $500 \mathrm{~km}$ length, is $\mathrm{M}_{\mathrm{w}} 8.7$ (Fig. 11). The magnitude uncertainty depends on the scaling relationship used, but more importantly on the segmentation model chosen (Fig. 11).

\subsection{Rupture recurrence interval associated with the APF}

We have obtained recurrence times for possible surface rupture of the APF from the estimated Mw and slip rate.
We have used the relationship developed by Wesnousky (1986):

$$
\mathrm{T}=\mathrm{M}_{\mathrm{o}} \mathrm{M}_{\mathrm{orate}}
$$

where $\mathrm{T}$ is the recurrence interval, Mo is the seismic moment and $\mathrm{Mo}_{\text {rate }}$ is the rate at which seismic moment is released. $\mathrm{M}_{\mathrm{o}}$ and $\mathrm{M}_{\mathrm{o} \text { rate }}$ are obtained from:

$$
\log \mathrm{M}_{\mathrm{o}}=16.05+1.5 \mathrm{M}_{\mathrm{w}} \text { (Hanks and Kanamori, 1979) }
$$

and

$$
\mathrm{M}_{\mathrm{orate}}=\mu \mathrm{A} \text { SR, }
$$

where $\mu$ is the crustal rigidity $\left(3 \times 10^{11}\right.$ dynes $\left./ \mathrm{cm}^{2}\right), \mathrm{A}$ is the fault area (we have used a seismogenic crustal depth of $20 \mathrm{~km}$ ) and SR is the slip rate.

The recurrence intervals (RI) for rupture of the APF range from $10 \mathrm{ka}$ to $\sim 4 \mathrm{Ma}$ depending on the segmentation model and the slip rate used (Table 2; Appendix 2). Minimum recurrence times (of the order of tens of thousands of years) are obtained for a maximum segmentation model (i.e., shortest possible rupture lengths) and maximum slip rate. The maximum recurrence interval (of $4 \mathrm{Ma}$ ) is obtained for a whole fault rupture and minimum slip rate. $\mathrm{Mw}$ and recurrence intervals obtained here are very preliminary and have large uncertainties because they are not 
based on specific paleoseismic data and, thus, they should only be used as a first order approximation. With the current data, is very difficult to assess the best estimate RI for the APF. It is likely that ruptures will tend to be short (maximum segmentation model) because the fault is slow and has small total displacement $(\sim 3 \mathrm{~km})$, and thus the fault plane is likely to have important asperities (Stirling et al., 1996). This can reduce the RI range to $20-30 \mathrm{ka}$ if we use the mean slip rate value (Table 2).

\section{Contribution of the APF and other slow slip faults in the interior of Iberian Peninsula to seismic hazard}

We have calculated the contribution of the APF and other slow slip faults to the seismic hazard of the interior of the Iberian Peninsula. Our aim is to assess whether the identified fault structures pose a risk to society in this region. We have approached this assessment in two ways. Firstly, we assess the contribution to the probabilistic seismic hazard of a typical active fault representing the whole range of $\mathrm{Mw}$ and RI values of the area. This is a useful exercise to gain an understanding of the return period at which these faults may pose a hazard. Secondly, we produce probabilistic hazard maps by accumulating the contribution of all active and potentially active faults in the region (note that we only focus on the contribution from fault sources not from background seismicity in this study) .

For our first assessment we use the dataset of possible active fault sources (Figs. 1 and 12) that Villamor (2002) compiled for this region (Appendix 1). As mentioned above, fault slip rates in the region are difficult to obtain because faults are slow moving and geomorphic expression is very subtle. Early studies of slip rate values in Portugal (Cabral, 1995) pioneered active fault characterisation in the area. Recently (last $\sim 10$ years) active faults have been the focus of detailed studies and a few new slip rates have been obtained in the Iberian Peninsula (Villamor, 2002; Rockwell et al., 2009) and incorporated into hazard studies (e.g., Villamor, 2002). When slip rates have not been previously assessed, Villamor (2002) estimated them based on ages of displaced geological features, or assigned values of neighbouring faults of known slip rate when geomorphic similarities were present. We have updated that dataset and extracted information on the typical magnitude and slip rate values for faults in the area. These data sets are presented in Appendices 1 and 2 . Because of the scarce information on fault activity in this area we have assigned large uncertainties to slip rate values. We have used Villamor (2002) fault segmentation models (Fig. 12 and Appendix 2) and the typical fault segment lengths and associated earthquake magnitudes evident in the region.

The compilation showed that while the rupture lengths (and associated Mw values) of the APF are representative of the range of values obtained for faults in the wider region, the APF slip rate is within the lower range (Table 2; Appendix 2). Slip rates for faults in the interior of Iberia generally range from $<0.01$ to $\sim 0.2 \mathrm{~mm} /$ year, although the Lower Tagus and Manteigas-Bragança faults could exceed $0.5 \mathrm{~mm} /$ year.

To explore the effects that the variation of Mw and slip rate could have on a site close to an active fault for faults in the intraplate of Iberia, we use the APF and its segmentation model with segments that range in length from 20 to $500 \mathrm{~km}$ in length (representative of whole range of segment lengths for potentially active faults in this study,

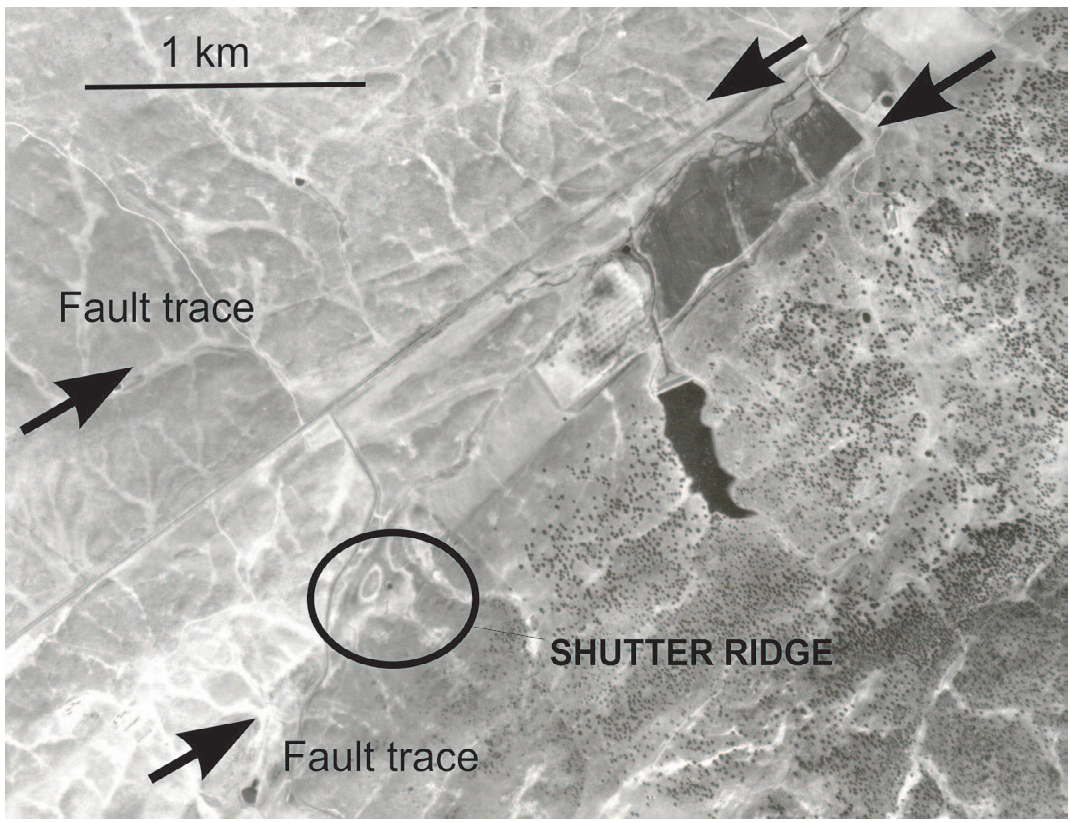

Fig. 10.- Recent fault scarps along the Alentejo-Plasencia Fault (IGN aerial photograph at 1:30.000 scale, 1985. Run H.M.N. 622, photo number 00012). Location of aerial photo shown in Fig. 5.

Fig. 10.- Escarpe de falla reciente a lo largo de la falla Alentejo-Plasencia (fotografía aérea del IGN a escala 1:30.000, 1985. Pasada H.M.N. 622, fotografía número 00012). La localización de la foto se muestra en la Fig. 5. 
Mw for potential fault segments in central and western lberia except Alentejo-Plasencia Fault

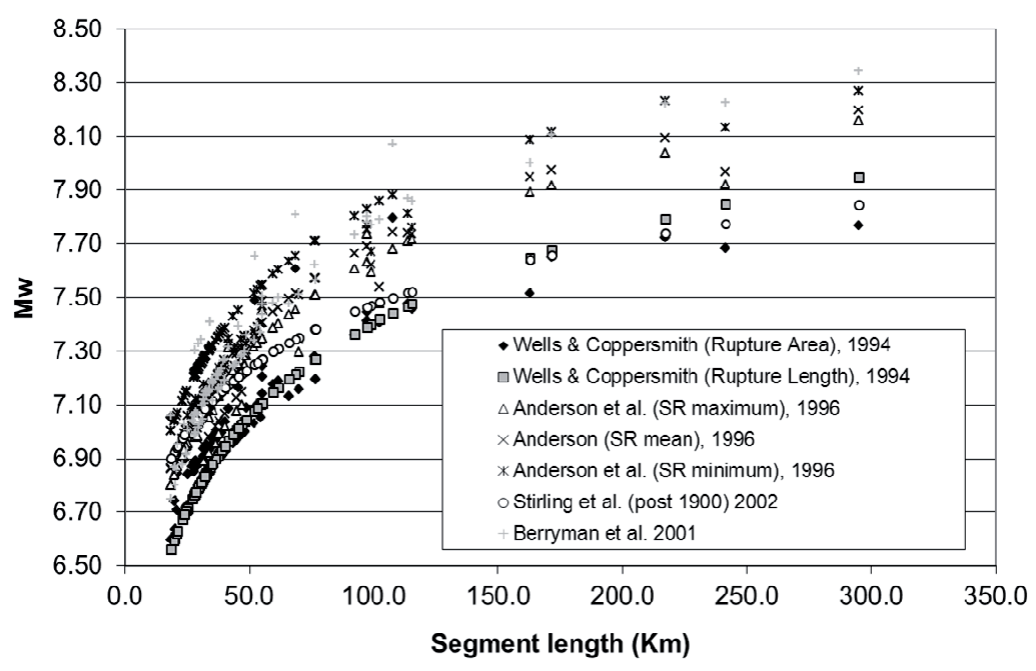

Mw for potential segments of Alentejo-Plasencia Fault

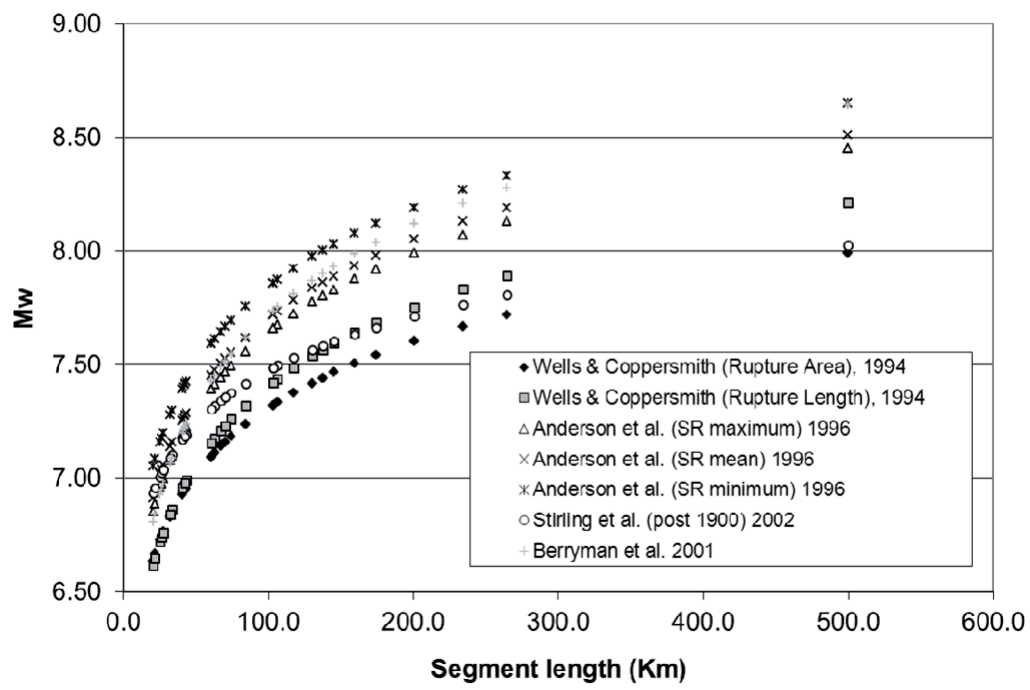

Fig. 11.- Mw estimates and segment lengths associated with active faults in the intraplate area of the Iberian Peninsula. Fault scaling relationships are: Wells and Coppersmith, 1994; Anderson et al., 1996; Stirling et al., 2002; and Berryman et al., 2001.

Fig. 11.- Magnitudes Mw estimadas y longitudes de segmentos asociadas con las fallas activas en el área intraplaca de la península Ibérica. La relaciones de escala son: Wells and Coppersmith, 1994; Anderson et al., 1996; Stirling et al., 2002; and Berryman et al., 2001.
Appendix 2), with slip rate values of $0.01,0.1$ and 0.5 $\mathrm{mm} /$ year (whole range of values for potentially active faults in this study, Appendix 2). Several hazard curves are developed for a site at Plasencia township, located within $1 \mathrm{~km}$ of the fault trace (Fig. 12 and 13). In this evaluation the only seismic sources are the different segments and segmentation options of the APF. The curves represent combinations of different segmentation models (i.e., different segment lengths and thus different possible earthquake magnitudes) and different possible slip rates on faults in the intraplate area of Iberia (Fig. 13).The seismic hazard assessment method uses procedures developed in Stirling et al. (2012) and Villamor (2002) which are based on the algorithms of Cornell (1968). We have used Atkinson y Boore (1995) attenuation relationship.
The hazard curves in Figure 13 show a great variability depending of the segmentation model and the slip rate value of choice. We consider a Peak Ground Acceleration (PGA) value of $0.3 \mathrm{~g}$ as the onset of significant damage even for structures with specific earthquake resilient. Faults with slip rate values of $0.01 \mathrm{~mm} / \mathrm{yr}$ and large segments (e.g., 1 segment of $500 \mathrm{~km}$; see APF parameters in Appendix 2) have no contribution to $0.03 \mathrm{~g}$ ground motions. Faults with $0,01 \mathrm{~mm} / \mathrm{yr}$ and maximum segmentation rate (13 segments with segment lengths ranging from 22 to $63 \mathrm{~km}$; see APF parameters in Appendix 2), only contribute to $0.3 \mathrm{~g}$ ground motions for return periods $\geq$ $1 \mathrm{Ma}$. Faults with $0.1 \mathrm{~mm} / \mathrm{yr}$ slip rate and any segmentation model, have an annual probability of exceedance of $0.3 \mathrm{~g}$ PGA $\geq 0.0008$ (that is for a return period $\geq 80,000$ 


\begin{tabular}{|c|c|c|c|c|c|c|c|c|c|c|}
\hline $\begin{array}{c}\text { Segmentation } \\
\text { model }\end{array}$ & Segment name & $\begin{array}{c}\text { Length } \\
(\mathrm{km})\end{array}$ & SR & $\begin{array}{c}M_{w} \\
W \& C \\
(R A)^{1}\end{array}$ & $\begin{array}{c}\mathrm{M}_{\mathrm{w}} \\
\text { Anderson }^{1} \\
\text { (TD media) }\end{array}$ & $\begin{array}{c}\mathrm{M}_{\mathrm{w}} \\
\text { Stirling } \\
\text { pos } 1900^{1}\end{array}$ & $\begin{array}{c}\mathbf{M}_{w} \\
\text { Berryman }^{1}\end{array}$ & $\begin{array}{c}\text { RI (years) } \\
\text { (Slip Rate min, } \\
\text { W\&C(RA)) }\end{array}$ & $\begin{array}{c}\text { RI (years) } \\
\text { (Slip Rate mean, } \\
\text { W\&C(RA)) }\end{array}$ & $\begin{array}{c}\text { RI (years) } \\
\text { (Slip Rate max } \\
\text { W\&C(RA)) }\end{array}$ \\
\hline $\begin{array}{l}\text { Minimum } \\
\text { (1 segment) }\end{array}$ & All & 500 & $0,1-0,01$ & 7.99 & 8.51 & 8.02 & 8.65 & 40540 & 81079 & 405395 \\
\hline \multirow{13}{*}{$\begin{array}{c}\text { Maximum } \\
\text { (13 segments) }\end{array}$} & AP1-Muñico & 41,88 & $0,1-0,01$ & 6.93 & 7.26 & 7.17 & 7.21 & 12639 & 25278 & 126388 \\
\hline & AP2 -Barco & 25,73 & $0,1-0,01$ & 6.73 & 7.02 & 7.00 & 6.93 & 10052 & 20105 & 100524 \\
\hline & AP3 -Jerte & 63,7 & $0,1-0,01$ & 7.11 & 7.47 & 7.32 & 7.45 & 15392 & 30785 & 153925 \\
\hline & AP4 -Cañave & 43,15 & $0,1-0,01$ & 6.95 & 7.28 & 7.18 & 7.23 & 12818 & 25635 & 128175 \\
\hline & AP5-Brozas & 26,8 & $0,1-0,01$ & 6.74 & 7.04 & 7.02 & 6.95 & 10247 & 20494 & 102468 \\
\hline & AP6-Aliseda & 34,13 & $0,1-0,01$ & 6.85 & 7.16 & 7.10 & 7.09 & 11480 & 22960 & 114799 \\
\hline & AP7-Alburq & 20,87 & $0,1-0,01$ & 6.64 & 6.91 & 6.93 & 6.81 & 9110 & 18221 & 91104 \\
\hline & AP8 -Campo & 22,31 & $0,1-0,01$ & 6.67 & 6.94 & 6.96 & 6.85 & 9401 & 18801 & 94006 \\
\hline & AP9 & 28,02 & $0,1-0,01$ & 6.76 & 7.06 & 7.03 & 6.98 & 10463 & 20927 & 104634 \\
\hline & AP10 & 32,82 & $0,1-0,01$ & 6.83 & 7.14 & 7.09 & 7.07 & 11271 & 22541 & 112706 \\
\hline & AP11 & 41,13 & $0,1-0,01$ & 6.93 & 7.25 & 7.17 & 7.20 & 12532 & 25064 & 125319 \\
\hline & AP12 & 44 & $0,1-0,01$ & 6.96 & 7.29 & 7.19 & 7.24 & 12936 & 25871 & 129356 \\
\hline & AP13 & 75 & $0,1-0,01$ & 7.18 & 7.56 & 7.37 & 7.55 & 16620 & 33241 & 166204 \\
\hline \multirow{6}{*}{$\begin{array}{c}7 \text { segments } \\
(6 \text { segments }+ \\
\text { AP13) }\end{array}$} & AP2,1 & 68.0 & $0,1-0,01$ & 7.14 & 7.51 & 7.34 & 7.49 & 15872 & 31745 & 158724 \\
\hline & $\mathrm{AP} 4,3$ & 107.0 & $0,1-0,01$ & 7.33 & 7.73 & 7.49 & 7.75 & 19641 & 39283 & 196414 \\
\hline & AP5, 6 & 61.0 & $0,1-0,01$ & 7.09 & 7.45 & 7.30 & 7.43 & 15082 & 30165 & 150823 \\
\hline & AP8,7 & 43.0 & $0,1-0,01$ & 6.95 & 7.28 & 7.18 & 7.23 & 12797 & 25593 & 127966 \\
\hline & AP10,9 & 61.0 & $0,1-0,01$ & 7.09 & 7.45 & 7.30 & 7.43 & 15082 & 30165 & 150823 \\
\hline & AP11,12 & 85.0 & $0,1-0,01$ & 7.24 & 7.62 & 7.41 & 7.62 & 17627 & 35255 & 176275 \\
\hline \multirow{4}{*}{$\begin{array}{c}5 \text { segments } \\
(4 \text { segments }+ \\
\text { AP13) }\end{array}$} & $\mathrm{AP} 3,2,1$ & 131.0 & $0,1-0,01$ & 7.42 & 7.84 & 7.56 & 7.87 & 21601 & 43203 & 216013 \\
\hline & AP $6,5,4$ & 104.0 & $0,1-0,01$ & 7.32 & 7.72 & 7.48 & 7.74 & 19381 & 38761 & 193807 \\
\hline & AP9, 8,7 & 71.0 & $0,1-0,01$ & 7.16 & 7.53 & 7.35 & 7.52 & 16198 & 32395 & 161977 \\
\hline & AP12,11,10 & 118.0 & $0,1-0,01$ & 7.38 & 7.78 & 7.53 & 7.81 & 20566 & 41132 & 205659 \\
\hline \multirow{3}{*}{$\begin{array}{c}4 \text { segments } \\
(3 \text { segments }+ \\
\text { AP13) }\end{array}$} & $\mathrm{AP} 4,3,2,1$ & 174.5 & $0,1-0,01$ & 7.54 & 7.98 & 7.66 & 8.04 & 24718 & 49435 & 247176 \\
\hline & AP8,7,6,5 & 104.0 & $0,1-0,01$ & 7.32 & 7.72 & 7.48 & 7.74 & 19381 & 38761 & 193807 \\
\hline & AP12,11,10,9 & 146.0 & $0,1-0,01$ & 7.47 & 7.89 & 7.60 & 7.93 & 22730 & 45461 & 227305 \\
\hline \multirow{3}{*}{3 segments } & AP5,4,3,2,1 & 201.0 & $0,1-0,01$ & 7.60 & 8.05 & 7.71 & 8.12 & 26416 & 52832 & 264159 \\
\hline & AP10,9,8,7,6 & 138.0 & $0,1-0,01$ & 7.44 & 7.86 & 7.58 & 7.90 & 22136 & 44273 & 221364 \\
\hline & AP13,12,11 & 160.0 & $0,1-0,01$ & 7.51 & 7.94 & 7.63 & 7.99 & 23730 & 47460 & 237301 \\
\hline \multirow{2}{*}{2 segments } & AP6,5,4,3,2,1 & 235.0 & $0,1-0,01$ & 7.67 & 8.13 & 7.76 & 8.21 & 28429 & 56858 & 284292 \\
\hline & AP13,12,11,10,9,8,7 & 265.0 & $0,1-0,01$ & 7.72 & 8.19 & 7.80 & 8.28 & 30081 & 60161 & 300807 \\
\hline
\end{tabular}

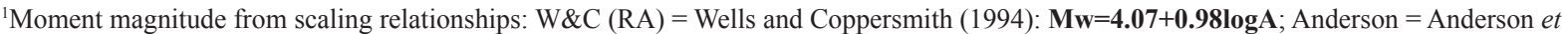

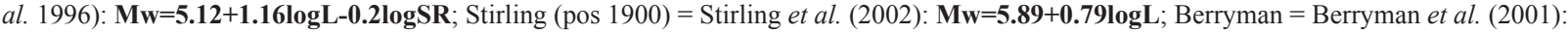
$\mathrm{Mw}=4.18+2 / 3 \log W+4 / 3 \log \mathrm{L}$

Table 2.- Seismic parameters of the APF (SR: slip rate; $\mathrm{M}_{\mathrm{w}}$ : moment magnitude; RI: recurrence interval)

Tabla 2.- Parámetros sísmicos de la FAP (SR: tasa de deslizamiento; $\mathrm{M}_{\mathrm{w}}$ : magnitud de movimiento; RI: intervalo de recurrencia)

years). Faults with slip rates of $0.5 \mathrm{~mm} / \mathrm{yr}$ have return periods of 60,000 to 10,000 years for minimum to maximum segmentation models, respectively.

Our second approach to assess the contribution of active faults to seismic hazard in intraplate Iberia is to produce a probabilistic peak ground acceleration map incorporating the contribution of all modelled faults in the region (Fig. 14). We consider that our best estimate source model is that with mean fault slip rate and maximum segmentation (e.g.: for APF it would be $0.05 \mathrm{~mm} /$ yr and 13 segments; for the Manteigas-Bragança fault is $0.04 \mathrm{~mm} / \mathrm{yr}$ and 5 segments; and so on; see Appendix 2 for all fault parameters). In such a low-strain area where faults have a small total displacement (e.g., APF has
$3 \mathrm{~km}$ ), faults are likely to have large and/or numerous asperities (Stirling et al., 1996) and thus faults are more likely to rupture in small segments. While for most of the study area PGA is $0.2 \mathrm{~g}$ for a 10,000 year return period, some areas show larger values (Fig. 14). For example, we obtain a PGA value of $>0.3 \mathrm{~g}$ in areas close to the fastest faults $(\geq 0.5 \mathrm{~mm} / \mathrm{yr}$ : Tejo Inferior and Vilariça faults) (Figs. 12a and 14). Also in areas surrounded by several faults PGA $>0.2 \mathrm{~g}$ are estimated (e.g. northern sector of the map in Fig 14). 
Fig. 12.- A) Map of possible active fault sources in the intraplate area of the Iberian Peninsula. Filled circles are sites where probabilistic hard assessments were undertaken. Fault names can be found in Appendix 2. Numbers indicate modelled fault segments for each fault. B) Vector sum of slip rate values of active faults in the intraplate area of Iberia. Profiles are developed along three lines (I, II and III) that are parallel to the maximum horizontal shortening direction (red lines; Herráiz et al., 2000). Black arrows are horizontal slip rate vectors for each fault crossed on each profile, and grey arrows are the summation of those individual fault vectors. Red arrows, and numbers, are the component of the vector sum that is parallel to maximum horizontal shortening direction.

Fig. 12.- A) Mapa de posibles falla como fuentes sismogenéticas en la región intraplaca de la península Ibérica. Los círculos sólidos son los lugares donde se llevó a cabo el cálculo de peligrosidad sísmica. Los nombres de las fallas se pueden encontrar en el anexo 2. Los números indican los segmentos modelizados para cada falla. B) Vector suma de los valores de velocidad de deslizamiento de las fallas activas en la región intraplaca de Iberia. Los perfiles se han calculado a lo largo de tres líneas (I, II and III) paralelas a la dirección de máximo acortamiento horizontal (líneas rojas; Herráiz et al., 2000). Las flechas negras representan los vectores de velocidad de deslizamiento para cada falla cruzada en el perfil, y las flechas grises muestran la suma de todos los vectores individuales de las fallas. Las flechas rojas, y los números, muestran las componentes del vector suma paralelas a la dirección de máximo acortamiento horizontal.

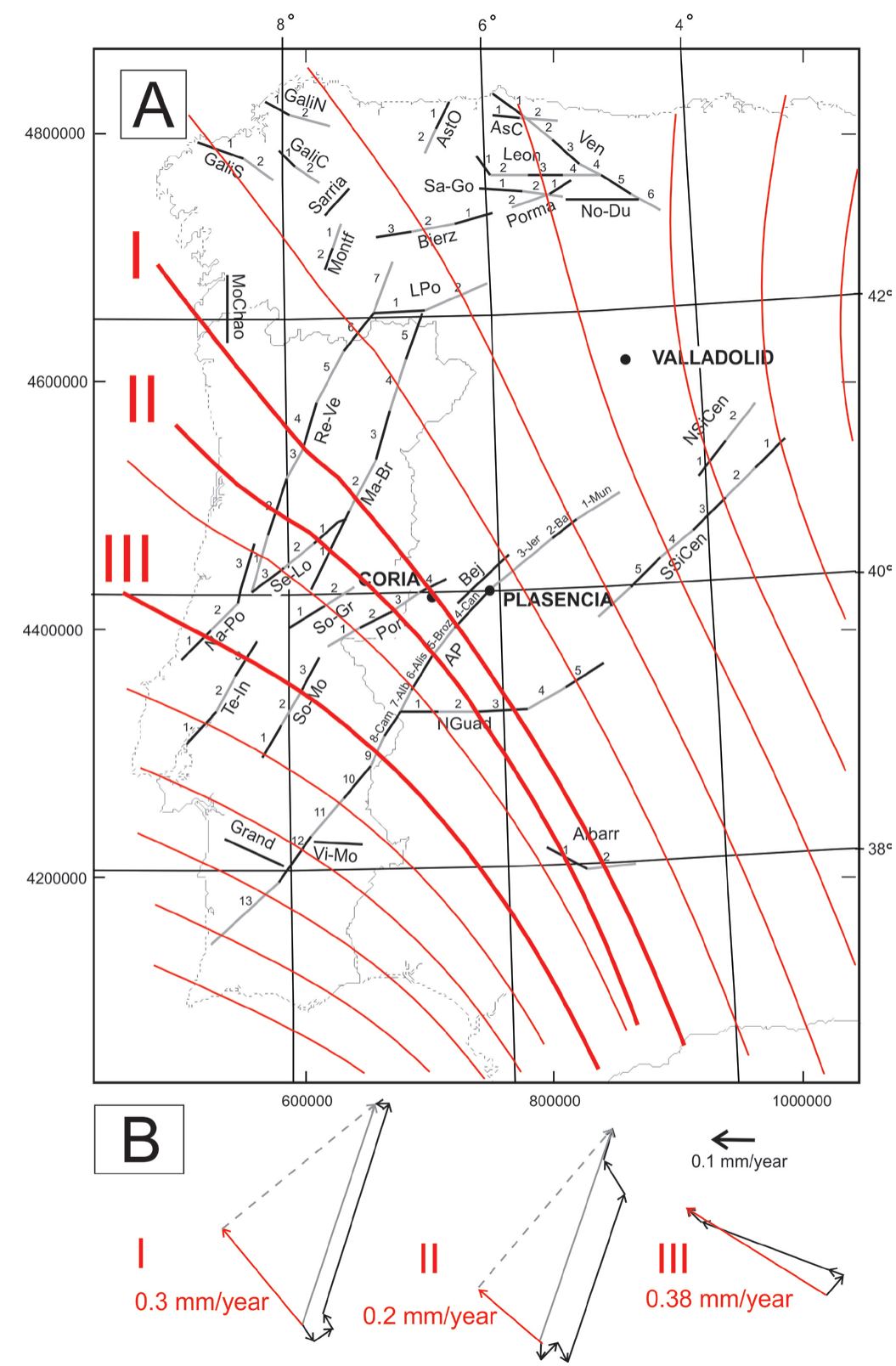

Active faults the intraplate of Iberia do not contribute significantly to seismic hazard at short return periods. However, they can be important contributors to hazard at critical facilities where return periods of interest may be 10,000 years or more. In figure 13 we show that if we choose, for example, a PGA value of $0.3 \mathrm{~g}$ as the threshold for earthquake shaking damage, then faults with a slip rate of $\sim 0.1 \mathrm{~mm} /$ year may pose a threat to critical facilities, such as nuclear power plants or nuclear waste repositories (usually designed for a probability of exceedance of $\sim 0.00001$ per annum, or return period of 100,000 years). Faults with slip rate values of the order of $0.5 \mathrm{~mm} /$ $\mathrm{yr}$, can exceed the 0.3 pga for the 10,000 year return period $(0.0001$ probability of exceedance of $0.3 \mathrm{~g})$ which is pertinent for high hazard dams and emergency response intraplate regions. 
Fig. 13.- Seismic hazard curves for a generic fault in the intraplate area of Iberian Peninsula. Note that we have used the segmentation model of the Alentejo-Plasencia fault because it suggests fault segments that range in length from $20-60 \mathrm{~km}$ (fault divided into 13 segments) to $500 \mathrm{~km}$ (fault has only 1 segment). Calculations were undertaken for a site at Plasencia township.

Fig. 13.- Curvas de peligrosidad sísmica para una falla genérica en la región intraplaca de la península Ibérica. Nótese que se ha utilizado el modelo de segmentación de falla Alentejo-Plasencia porque sugiere segmentos con longitudes que varían de 20-60 km (para el caso de considerar la falla dividida en 13 segmentos) a $500 \mathrm{~km}$ (considerando la falla como un solo segmento). Los calculus fueron realizado para un emplazamiento situado en la ciudad de Plasencia.

\section{Slip rate $(\mathrm{mm} / \mathrm{yr})$, number of segments}

$\begin{array}{ccc}-0.5,13 \mathrm{seg} & -0.1,13 \mathrm{seg} & -0.01,13 \mathrm{seg} \\ -0.5,7 \mathrm{seg} & -0.1,7 \mathrm{seg} & -0.01,7 \mathrm{seg} \\ -0.5,5 \mathrm{seg} & -0.1,5 \mathrm{seg} & -0.01,5 \mathrm{seg} \\ 0.5,4 \mathrm{seg} & -0.1,4 \mathrm{seg} & -0.01,4 \mathrm{seg} \\ 0.5,3 \mathrm{seg} & 0.1,3 \mathrm{seg} & -0.01,3 \mathrm{seg} \\ 0.5,2 \mathrm{seg} & 0.1,2 \mathrm{seg} & -0.01,2 \mathrm{seg} \\ 0.5,1 \mathrm{seg} & 0.1,1 \mathrm{seg} & 0.01,1 \mathrm{seg}\end{array}$

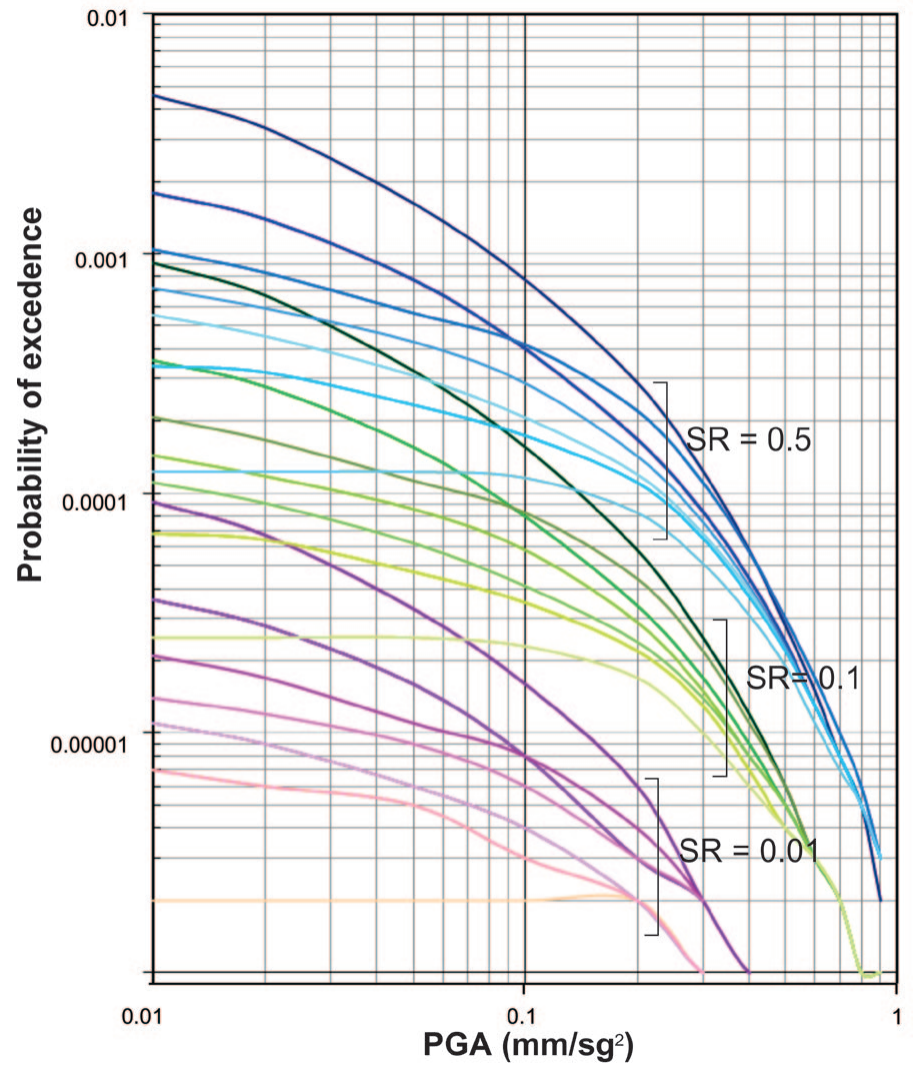

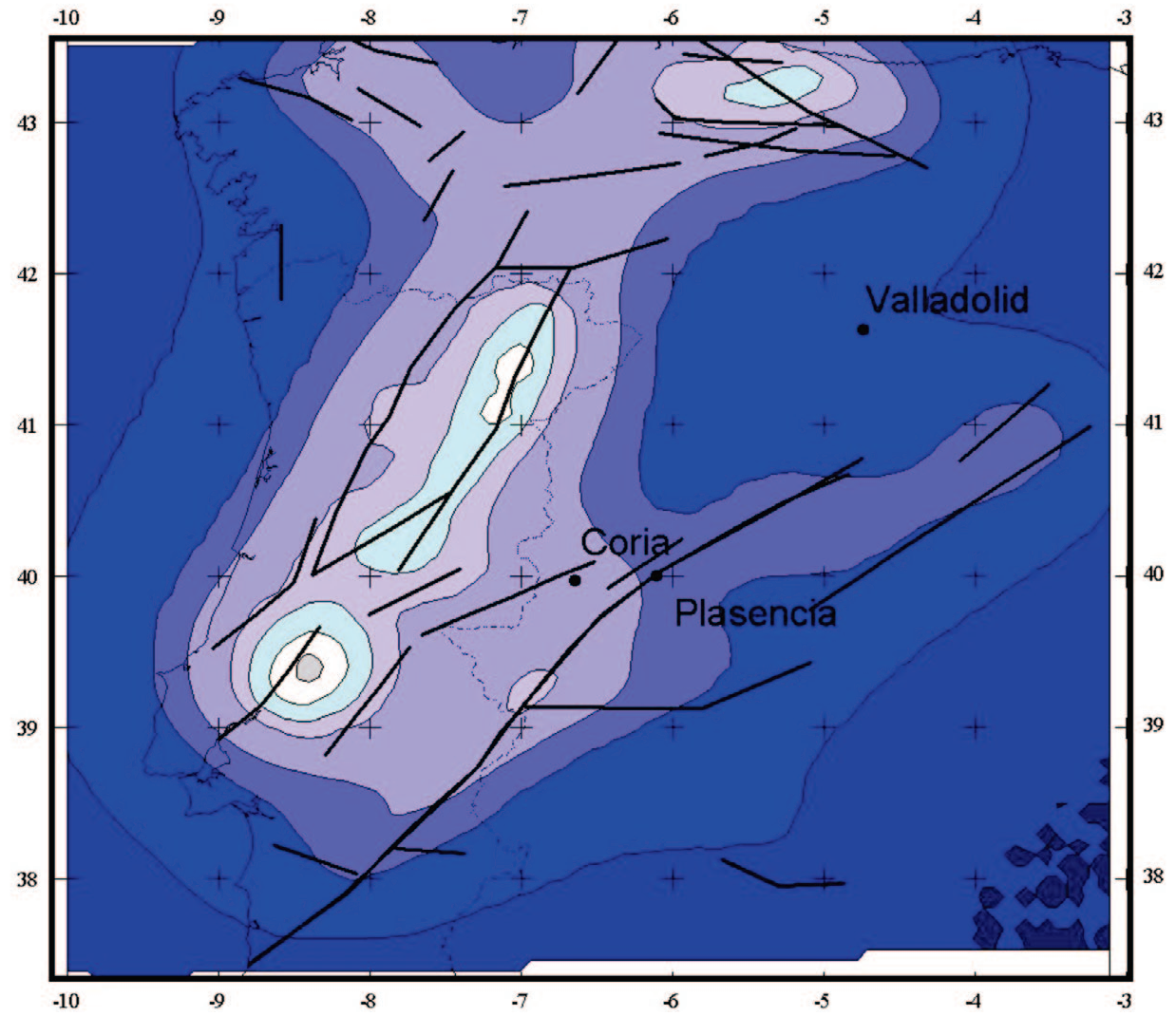

Peak ground
acceleration $(\mathrm{g})$
for a 100 year
return period

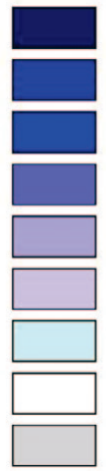

$0.005-0.01$

$0.01-0.05$

0.05-0.1

$0.1-0.15$

0.15-0.2

$0.2-0.25$

0.25-0.3

$0.3-0.35$

0.35-0.4

Fig. 14.- Contribution of all fault sources to probabilistic seismic hazard of central and western Iberia for a 10,000 year return period. Note that seismic hazard values do not include contribution from background seismicity.

Fig. 14.- Contribución de todas las fallas como fuentes sismogenéticas a la peligrosidad sísmica probabilista en la zona central y oriental de Iberia para un periodo de retorno 10000 años. Nótese que los valores de peligrosidad sísmica no incluyen la contribución de la sismicidad de fondo. 
facilities. For return periods of 475 years (probability of exceedence of $10 \%$ in 50 years), typical for the design of residential buildings, active faults in the intraplate of the Iberian Peninsula with slip rates of $\leq 0.5 \mathrm{~mm} / \mathrm{yr}$ do not contribute to the hazard.

The combined contribution of several faults to the seismic hazard at a site is illustrated in figure 14, which represents the seismic hazard of our preferred model (mean slip rate and maximum segmentation model). The maximum expected PGA for a return period of 10,000 years occurs close to faults with $\sim 0.5 \mathrm{~mm} / \mathrm{yr}$ slip rate but particularly in proximity to several faults (i.e., such as areas with values $>0.25$ PGA in the central part of figure 14). The combined effect of several faults is also evident when comparing the results for Plasencia and Coria towns. While both are located close to faults with similar low slip rate, the higher PGA of Coria is attributed to the contribution of several nearby faults (Fig. 14). This effect is also observed at the intersection of the APF and the North Guadiana Fault.

This sensitivity analysis raises the question as to whether there is merit in studying low slip rate $(<0.01 \mathrm{~mm} / \mathrm{yr})$ faults in the western and central Iberian Peninsula if they do not pose a risk to the society (except for nearby nuclear power plants and other critical facilities). There are two main reasons why we should. Firstly, the confidence in the preliminary slip rate values presented here is low. Specific paleoseismic studies that provide confident assessments of slip rate have only been developed on a few faults. Current estimates of fault slip rates of $0.1 \mathrm{~mm} /$ yr used in this study present such high uncertainties that they could be easily re-evaluated to $\geq 0.5 \mathrm{~mm} / \mathrm{yr}$ in future site specific projects. Secondly, only if we gain a full understanding of the way that deformation is distributed across the whole Iberian Peninsula, and how that total deformation budget is absorbed, can we be sure that the slip rate values assigned to each fault are in the correct range.

A first attempt to assess whether the fault slip rate ranges estimated here are reasonable is shown on figure $12 \mathrm{~b}$. In this figure, we add the deformation as described by fault slip rates across the intraplate area of the Iberian Peninsula. We sum the component of the slip rate in the direction of the maximum horizontal shortening axis of the stress tensor (Herráiz et al., 2000) in several transects. This indicates that, consistently across several transects, at least 0.2 to $0.4 \mathrm{~mm} / \mathrm{yr}$ (approximately 5 to $10 \%$ of the total plate boundary relative motion), may occur within intraplate Iberia. Improvement on this assessment could be achieved by assessing the whole plate boundary deformation budget in a consistent way, and by including other deformation measurements, such as GPS velocities. The partitioning of plate boundary strain into the intraplate re- gion of Iberia has significant implications for the seismic hazard of the Iberian Peninsula, the development of appropriate codes for different building and infrastructure types, and decisions on land use planning.

\section{Conclusions}

The APF is one of the active faults of the interior of the Iberian Peninsula. We consider that a fault is active if it has moved within the current tectonic regime and that the tectonic regime has not changed since the Neogene in the interior of Iberia. The APF displays clear deformation of geomorphic surfaces and sediments of Neogene and younger age.

We have characterised the earthquake potential of the APF. We have estimated the slip rate of the fault from displacements of geological formations and geomorphic surfaces. APF slip rate ranges from 0.01 to $0.1 \mathrm{~mm} / \mathrm{yr}$ with a best estimate of $0.05 \mathrm{~mm} / \mathrm{yr}$. We have also segmented the fault based on geometric features and obtained different segmentation models: a maximum segmentation model (shortest segments) with segments lengths ranging from 20 to $75 \mathrm{~km}$; and minimum segmentation model of one segment of $500 \mathrm{~km}$ in length. We have assigned earthquake magnitudes to fault rupture using international empirical relationships that use fault length and obtained $\mathrm{M}_{\mathrm{w}}$ values from 6.6 to 8.7. Those parameters have been used to assess possible recurrence intervals for fault rupture with values ranging from $10 \mathrm{ka}$ to $4 \mathrm{Ma}$. Our preferred model of maximum segmentation (i.e. shortest segments) and mean slip rate achieved $M_{w}$ values of 6.6 to 7.6 and recurrence intervals of 20 to $30 \mathrm{ka}$.

A compilation of active fault parameters in the area shows that the $M_{w}$ range estimated for the APF is representative of the whole area. However, the APF slip rate is in the lower part of the range for all active faults in the area with maximum values of $0.5-0.8 \mathrm{~mm} / \mathrm{yr}$.

We have calculated hazard curves including contributions from all fault sources and we conclude that active faults of the intraplate Iberia do not contribute significantly to seismic hazard at short return periods typical of the building codes ( $\sim 500$ year return periods). However, they can be important contributors to hazard at critical facilities (high hazard dams, nuclear power plants, emergency response buildings) where return periods of interest may be 10,000 years or more. Our fault source characterisation is very preliminary (with large uncertainties) and further detailed studies of active faults across the whole plate boundary are required to confirm the values for the intraplate faults presented here. 


\section{Acknowledgements}

We thank Luis I. González de Vallejo for financial support and comments on early versions of this study. We also thank Tatiana Goded and Kate Clark for reviewing an early draft of the manuscript, and Rosa Tejero and Julian García-Mayordomo for journal reviews. Monica Cabeza, Elena Villamor, Michelle Park and Angel Vírseda helped with production of figures, tables and appendices. This study was jointly funded by Universidad Complutense de Madrid (Spain), ENRESA S.A. (Spain) and GNS Science (New Zealand).

\section{References}

Alonso J.L., Pulgar, J.A., García-Ramos, J.C., Barba, P. (1996): Tertiary basins and Alpine Tectonics in the Cantrabian Mountains (NW Spain). In: P.F. Friend, C.J. Dabrio (ed.), Tertiary Basins of Spain. World and regional geology series (6). Cambridge University Press, Cambridge, New York: 214-227.

Anderson, J.G., Wesnousky, S.G., Stirling, M.W. (1996): Earthquake size as a function of fault slip rate. Bull. Seis. Soc. America 86, 683-690.

Anderweg, B. (2002): Cenozoic tectonic evolution of the Iberian Peninsula, causes and effects of changing the stress field. $\mathrm{PhD}$ Thesis. Vrie University, Amsterdam (The Netherlands): 178 p.

Arthaud, F., Matte, P. (1975): Les décrochements tardi-hercyniens du sud-ouest de l'Europe. Geometyrie et essai de reconstitution des conditions de la déformation. Tectonophysics, 25: 139-171. doi:10.1016/0040-1951(75)90014-1

Atkinson, G.M., Boore, D.M. (1995): New Ground-Motion Relations for Eastern North America. Bull. Seis. Soc. America 85(1), 17-30.

Baena, J., Bardaji, T., Goy, J.L., Silva, P.G., Somoza, L., Zazo, C. (1991): An attempt of fault activity data file and map modellization. Bull. INQUA Neotectonics Comm. 16, 48-54.

Baena, R., Díaz, F. (1997): Resultados paleomagnéticos de la raña del Hespérico Meridional (Montoro, Córdoba). Geogaceta 21, 31-34.

Bascones-Alvira, L., Martín-Herrero, D. (1987): Hoja geológica 622 (Torrejoncillo). Mapa Geológico de España E. 1:50.000. Segunda serie, I.G.M.E., Madrid.

Berryman, K.R.; Webb, T.H.; Hill, N.; Stirling, M.W.; Rhoades, D.A.; Beavan, R.J.; Darby, D.J. (2001): Seismic loads on dams Waitaki System, earthquake source characterisation. Institute of Geological and Nuclear Sciences client report 2001/129, New Zealand: 79 p.

Brum da Silveira, A. (1990): Neotectónica e Sismotectónica da Região Vidigueira-Moura. MSc Thesis. Univ. Lisboa, Portugal: 204 p.

Brum da Silveira, A., Cabral, J., Perea, H., Ribeiro, A. (2009): Evidence for coupled reverse and normal active faulting in W Ibéria. The Vidigueira-Moura and Alqueva faults (SE Portugal). Tectonophysics 474, 184-199.

Cabral, J. (1989): An example of intraplate neotectonic activity, Vilariça basin, Northeast Portugal. Tectonics 8, 285-303. doi:10.1016/j. tecto.2009.04.013.

Cabral, J. (1995): Neotectonica em Portugal Continental. Memor. do Int. Geol. e Min. 31, 263 p.

Calvo, J.P., Daams, R., Morales, J., López-Martínez, N., Agusti, j., Anadon, P., Armenteros, I., Cabrera, L., Civis, J., Corrochano, A., Díaz-Molina, M., Elizaga, E., Hoyos, M., Martín-Suarez, E., Martínez, J., Miossent, E., Muñoz, A., Pérez-García, A., Pérez-González, A., Portero, J.M., Robles, F., Santisteban, C., Torres, T., Van der Meulen, A.J., Vera, J.A., Pein, P. (1993): Up-to-date Spanish conti- nental neogene synthesis and paleoclimatic interpretation. Rev. Soc. Geol. España 6(3-4), 29-39.

Capote, R., Muñoz, J.A., Simón, J.L., Liesa, C.L., Arlegui, L.E. (2002): Alpine tectonics I: the Alpine system north of the Betic Cordillera. In: Gibbons, W., Moreno, T. (ed.), The Geology of Spain. Geological Society, London: 367-400.

Capote, R., Villamor, P., Tsige, M. (1996): Tectónica alpina de la falla de Alentejo-Plasencia Fault, Macizo Hespérico. Geogaceta 7 (4), 917-920.

Capote, R., Villamor, P. (1999): La falla de Alentejo-Plasencia, un desgarre cortical de la colisión Alpina. In: Libro Homenaje a J. Ramirez del Pozo. Asoc. Geol. Geofis. Petrol. España: 151-158.

Carvalho, J., Cabral, J., Gonçalves, R., Torres, L., Mendes-Victor, L. (2006): Geophysical methods applied to fault characterization and earthquake potential assessment in the Lower Tagus Valley, Portugal. Tectonophysics 418, 277-297. doi:10.1016/j.tecto.2006.02.010

Cornell, C.A. (1968): Engineering seismic risk analysis. Bull. Seis. Soc. America 58(5): 1533-1606.

Crone, A.J., Machette, M.N., Bowman, J.R. (1992): Geologic investigations of the 1988 Tennant Creek, Australia, earthquakes; implications for paleoseismicity in stable continental regions, U.S. Geological Survey Bulletin B 2032-A, A1-A51.

De Vicente, G., González-Casado, J.M., Muñoz-Martín, A., Giner, J., Rodríguez-Pascua, M.A. (1996): Structure and Tertiary evolution of the Madrid Basin. In: P.F. Friend, C.J. Dabrio (ed.), Tertiary Basins of Spain. Cambridge University Press, Cambridge, New York: 263-267.

De Vicente, G., Vegas, R., Guimerá, J., Muñoz, A., Casas, A., Martín Velazquez, S., Heredia, N., Rodríguez-Fernández, R., González Casado, J.M., Cloetingh, S., Andeweg, B., Alvarez, J., Olaiz, A. (2004): Evolución geodinámica y cenozoica de la placa ibérica y su registro en el antepaís. In: Vera, J.A. (ed.), Geología de España. S.G.E.-I.G.M.E., Madrid: 597-602.

De Vicente, G., Cloetingh, S., Van Wees, J.D., Cunha, P.P. (2011): Tectonic classification of Cenozoic Iberian foreland basins. Tectonophysics 502, 38-61. doi:10.1016/j.tecto.2011.02.007.

Dias, R.P., Cabral, J. (1991): Neogene and Quaternary reactivation of the Ponsul River fault (Central Portugal). Pub. IGN Ser. Mon. 8, 269-282.

DeMets, C., Gordon, R.G., Argus, D.F., Stein, S. (1990): Current plate motions. Geophys. J. Int. 101, 425-478. doi: 10.1111/j.1365246X.1990.tb06579.x.

DeMets, C., Gordon, R.G., Argus, D.F., Stein, R. (1994): Effect of recent revisions to the geomagnetic reversal time scale on estimates of current plate motions. Geophys. Res. Lett, 21, 2191-2194. doi:10.1029/94GL02118.

Dewey, J. F., Helman, M. L., Turco, E., Hutton, D. H. W., Knott S. D. (1989): Kinematics of the western Mediterranean. In: M. P. Coward, D. Dietrich,, R.G. Park (ed.), Alpine tectonics. Geological Society Special Publications, London, 45, 265-283. doi:10.1144/ GSL.SP.1989.045.01.15.

Del Valle Lersundi, J. (1959): Breve nota sobre la existencia de una importante falla en el SW de nuestra Península. Not. Com. Inst. Geol. y Min., 82 (3-4), 346-350.

Eurocode 8 (2006): Design of structures for earthquake resistance. British-Adopted European Standard, UK.

Fernández Macarro, B., Blanco Sánchez, J.A. (1990): Evolución Morfológica de la Depresión de Talavan-Torrejón El Rubio, Cáceres. I Reunión Nacional de Geomorfología, Teruel: 753-762.

Fonseca, J., Bossi, V., Vilanova, S. Meghraoui, M. (2000): Investigations unveil Holocene thrusting for onshore Portugal. EOS 81, 412-413.

García Abad, F., Martín Serrano, A. (1980): Precisiones sobre la génesis y cronología de los relieves apalachianos del Macizo Hespérico (Me- 
seta Central Española). Estudios Geologicos 36, 391-401.

García de Figuerola, L.C. (1963): El dique diabásico del norte de Extremadura. Not. Com. Inst. Geol. Min. España 69, 43-78.

García de Figuerola, L.C. (1965): La continuación hacia el SO del dique básico de Plasencia (Cáceres). Not. Com. Inst. Geol. Min. España: $77 \mathrm{p}$.

Gracia Prieto, F.J., Moreno, F., Nozal, F. (1991): Neotectonics and associated seismicity in northwestern Duero Basin. Pub. IGN Mon. 8: 255-267.

Gonçalvez, F., Torre de Assunção, C. (1970): Noticia explicativa da floha 37-A (Elvas). Carta Geológica de Portugal na E. 1/50.000. Serviços Geológicos de Portugal: 50 p.

Gonçalvez, F., Torre de Assunção, C., Pinto Coelho, A.V. (1972): Noticia explicativa da floha 33-C (Campomaior). Carta Geológica de Portugal na E. 1/50.000. Serviços Geológicos de Portugal: 41 p.

González-Casado, J. M., Giner Robles, J. (2000): Relaciones entre fallas y sismicidad en el Noroeste peninsular. Geogaceta 28: 71-75.

González Vallejo. L., Capote del Villar, R., Villamor Pérez, P., Rodriguez Franco, J.A., Tsige, M. (1997): Metodología de Evaluación de Riesgo Sísmico en segmentos de falla. ENRESA Pub. Tec. num. 02/97, Madrid: 205 p.

González Flores, M. (1996): Estudio estructural del sector norte de la falla de Plasencia-Alentejo (Provincia de Avila y Cáceres). Trabajo de Investigación del curso de Doctorado de Geología Estructural. Universitat Autonoma de Barcelona, Barcelona: 71 p.

Hanks, T. C., H. Kanamori (1979): A moment magnitude scale, J. Geophys. Res. 84, 2348-2350. doi:10.1029/JB084iB05p02348.

Herráiz, M., De Vicente, G., Lindo-Ñaupari, R., Sanchez Cabañero, J.G. (1996): Seismotectonics of the Sierra Albarrana area (southern Spain); constraints for a regional model of the Sierra Morena-Guadalquivir Basin. Tectonophysics 266(1-4), 425-442. doi:10.1016/ S0040-1951(96)00201-6.

Hernández-Pacheco, F., Crusafont Pairo, M. (1960): Primera caracterización paleontológica del Terciario de Extremadura. Bol. R. Soc. Esp. Hist. Nat. 58, 275-283.

Herráiz, M., De Vicente, G., Lindo, R., Giner, J., Simón, J.L., González Casado, J.M., Vadillo, O., Rodríguez Pascua, M.A., Cicuéndez, J.I., Casas, A., Cabañas, L., Rincón, P., Cortés, A., Ramírez, M., Lucini, M. (2000): The recent (upper Miocene to Quaternary) and present tectonic stress distributions in the Iberian Peninsula. Tectonics 19(4),762-786. doi:10.1029/2000TC900006.

ITGE (1995): (Baleares y Canarias) Mapa Geológico de la Península Ibérica E. 1:000.000. I.T.G.E., Madrid.

Lepvrier, C., Martínez-García, E. (1990): Fault develpoment and stress evolution of the post-Hercynian Asturian Basin (Asturias and Cantrabria, Spain). Tectonophysics 184, 345-356. doi:10.1016/00401951(90)90447-G.

López-Fernández, C., Pulgar, J. A., Gallart, J., Glez-Cortina, J. M., Díaz, J., Ruíz, M. (2004): Sismicidad y tectónica en el área de Becerreá-Triacastela (Lugo, NO España). Geogaceta 36, 51-54.

Martín-González, F. (2009): Cenozoic tectonic activity in a Variscan basement: Evidence from geomorphological markers and structural mapping (NW Iberian Massif). Geomorphology 107, 210-225. doi:10.1016/j.geomorph.2008.12.008.

Martín Herrero D., Bascones Alvira, L., Ugidos Meana, J.M. (1987a): Hoja geologica num. 623 (Malpartida de Plasencia). Mapa Geológico de España, E. 1:50.000. Segunda serie, I.G.M.E., Madrid.

Martín Herrero, D., Bascones Alvira, L., Corretge Castañon, L. G. (1987b): Hoja geologica num. 650 (Cañaveral). Mapa geologico de Espana E. 1:50 000. Segunda serie, I.G.M.E., Madrid.

Martín Parra, L.M. (1987): Hoja geologica num. 128 (Riello). Mapa Geológico de España E. 1:50.000. Segunda serie, I.G.M.E., Madrid.
Martín-Serrano, A. (1991a): La definición y el encajamiento de la red fluvial actual sobre el Macizo Hespérico en el marco de su geodinámica alpina. Rev. Soc. Geol. España 4, 338-351.

Martín-Serrano, A. (1991b): El relieve del Macizo Hespérico y sus sedimentos asociados. En Alteraciones y paleoalteraciones en la morfología del oeste peninsular. Zócalo y cuencas terciarias. Monografía ${ }^{\circ}$ 6. I.G.M.E.-S.G.E., Madrid: 9-26.

Martín-Serrano, A. (1994): El relieve del Mazizo Hespérico: Génesis y cronología de los principales elementos morfológicos. Cuaderno Lab. Xeolóxico de Laxe 19, 37-55.

Martín-Serrano, A., Santisteban, J.I., Mediavilla, R. (1996): In: P.F. Friend, C.J. Dabrio (ed.), Tertiary Basins of Spain. World and regional geology series (6). Cambridge University Press, Cambridge, New York: 255-261.

Martínez J.M Solares, J. Mezcua (2002): Catalogo sísmico de la Península Ibérica (800aC-1900). I.G.N. monografía 18, Madrid: $253 \mathrm{p}$.

Martínez-Díaz, J.J., Capote, R., Tsige, M., Villamor, P., MartínGonzález, F., Insua-Arévalo, J .M. (2006): Seismic triggering in a stable continental area: The Lugo 1995-1997 seismic sequences (NW Spain). Journal of Geodynamics 41, 440-449. doi:10.1016/j. jog.2006.01.001.

Molina, E., Blanco, J.A., Pellitero, E., Cantano, M., Jorda, J. (1985): Esquema sobre la evolución del relieve del Mazizo Hespérico en su sector Castellano-Extremeño. Stvdia Geológica Salmaticensia $\mathrm{XX}, 115-126$.

MOPT (1992): Análisis sismotectónico de la Península Ibérica, Baleares y Canarias. M.O.P.T. Pub Tec. 26, Madrid.

Moreno Serrano, F. (1990): Superficies de erosión y fracturas en el enlace entre la Meseta Norte y la llanura extremeña (Salamanca-Cáceres). I Reunión de Geomorfología. Teruel: 39-49.

Muñoz-Martín, A., De Vicente, G. (1998): Origen y relación entre las deformaciones y esfuerzos alpinos dela zona centro-oriental de la Península Ibérica. Rev. Soc. Geol. España 11(1-2), 57-70.

Muir Wood R., Mallard, D.J. (1992): When is a fault extinct? J. Geol. Soc of London 149, 251-255. doi:10.1144/gsjgs.149.2.0251.

NCSE02 (2002): Real Decreto 997/2002, de 27 de septiembre, por el que se aprueba la norma de construcción sismorresistente: parte general y edificación (NCSR-02). Boletín Oficial del Estado, October 11 th, $n^{\circ} .244,35898-35967$.

Nozal, F., Gracia , F.J. (1990): El piedemonte de la Sierra del Brezo (Montes Palentinos). Reunión Nacional. de Geomorfología, Teruel: 763-772.

Parga Pondal. J.R. (1969): Sistemas de fracturas tardihercínicas del Macizo Hespérico. Trabajos del Laboratorio Xeológico de Laxe 37, $1-15$.

Pérez González, A., Cabra P., Ancoechea, E. (1989): Depresión del Tajo. Mapa del Cuaternario de España E 1:1.000.000, Memoria. I.T.G.E, Madrid: 175-186.

Pimentel, N.L. (1997): In: J. P. Calvo, J. Morales (ed.), A bacia terciária do Sado (SW Ibérico)- Sintese evolutiva e factores de controlo. Avances en el conocimiento del Terciario Ibérico. CSIC, Madrid: 217-220.

Pimentel, N., Azevedo, T. (1989): Evolução Plio-Quaternaria da serra de Grândola. Revis. Geoc. Do MNHN: 17-19.

Pimentel, N., Azevedo, T. (1992): Sobre la evolução do relevo e sedimentação quaternária no Baixo-Alentejo (Alvalade-Panóias). Gaia 4, 21-24.

Pimentel, N., Azevedo, T. (1994): Etapas e controlo alpino da sedimentação na bacia do Sado (SW de Portugal). Cuad. Lab. Xeol. De Laxe 19, 229-238.

Quesada García, A. (1960): Falla de desgarre en el SW de la Península Ibérica. Notas y Comunicaciones de Instituo Geol. y Min. de España 
58, 163-182.

Quigley, M., Van Dissen, R., Villamor, P., Litchfield, N., Barrell, D., Furlong, K., Stahl, T., Duffy, B., Bilderback, E., Noble, D., Townsend, D., Begg, J., Jongens, R., Ries, W., Claridge, J., Klahn, A., Mackenzie, H., Smith, A., Hornblow, S., Nicol, R., Cox, S., Langridge, R., Pedley, K. (2010): Surface rupture of the Greendale Fault during the Mw 7.1 Darfield (Canterbury) earthquake, New Zealand: initial findings. Bulletin of the New Zealand Society for Earthquake Engineering 43(4), 236-242.

Quigley, M., Van Dissen, R., Litchfield, N., Villamor, P., Duffy, B., Barrell, D, Furlong, K., Stahl, T., Bilderback, E, Noble, D. (2012): Surface rupture during the $2010 \mathrm{Mw} 7.1$ Darfield (Canterbury) earthquake: Implications for fault rupture dynamics and seismichazard analysis. Geology 40, 55-58. doi:10.1130/G32528.1.

Rincón, P.J., Hermosilla, J., Vegas, R., Pascual, G., Muñoz-Martín, A., Martínez-Solares, J.M. (2000): Cálculo automático del desplazamiento en un sector del sistema falla-dique de Plasencia. Geogaceta 27, 143-146.

Rockwell, T., Fonseca, J., Madden, C., Dawson, T., Owen, L.A., Vilanova, S., Figueiredo, P. (2009): Paleoseismology of the Vilariça Segment of the Manteigas-Bragança Fault in Northeastern Portugal. Geol. Soc. London, Special Publication 316, 237-258. doi:10.1144/ SP316.15.

Rodgers, D.A. (1980): Analysis of pull-apart basin development produced by en echelon strike-slips faults. Spec. Publ. Int. Sediment. 4, 27-41.

Rueda, J., Mezcua, J. (2001): Sismicidad, sismotectónica y peligrosidad sísmica en Galicia. Publicación Técnica. Instituto Geográfico Nacional, Madrid: 64 p.

Sánchez-Serrano, F. (2000): Análisis de la Topografia y Deformaciones Recientes en el Centro de la Península Ibérica. PhD Thesis. University Complutense, Madrid (Spain): 202 p.

Santanach, P. (1994): Las cuencas terciarias gallegas en el marco tectónico regional. Cuad. Lab. Xelógico de Laxe 18, 57-71.

Santisteban, J.I., Martín-Serrano, A., Mediavilla, R. (1991): El Paleógeno del sector suroccidental de la Cuenca de Duero: Nueva divisón estratigráfica y controles sobre su sedimentación. Acta Geológica Hispánica 26, 133-148.

Santisteban, J.I., Mediavilla, R., Martín-Serrano, A. (1996): The Duero Basin: a general overview. In: In: P.F. Friend, C.J. Dabrio (ed.), Tertiary Basins of Spain. World and regional geology series (6). Cambridge University Press, Cambridge, New York: 183-187.

Santos García, J.A., Casas Ruíz, J. (1982): Hoja geol. Num. 727 (Alburquerque). Mapa Geológico de España E. 1:50.000. Segunda serie, I.G.M.E., Madrid.

SGE (Servicio Geográfico del Ejército) (1997): Mapa militar digital de España. E. 1:250.000 y 1:800.000. Version 1.5, Ministerio de Defensa, Madrid.

Srivastava, S. P., Roest, W. R., Kovacs, L. C., Oakey, G., Levesque, S., Verhoef J. Macnab, R. (1990): Motion of Iberia since the Late Jurassic: Results from detailed aeromagnetic measurement in the Newfoundland Basin. Tectonophysics 184, 229-260. doi:10.1016/0040-1951(90)90442-B.

Stampfli, G., Borel, G. (2002): A plate tectonic model for Paleozoic and Mesozoic constrained by dynamic plate boundaries and resotred synthetic ocean isochrotnes. Earth and Planetary Science Letters 196, 17-33. doi:10.1016/S0012-821X(01)00588-X

Stirling, M.W., Rhoades, D., Berryman, K. (2002): Comparison of earthquake scaling relations derived from data of the instrumental and pre-instrumental eras. Bull. Seis. Soc. America 92 (2), 812-830. doi: $10.1785 / 0120000221$.

Stirling, M.W., McVerry, G., Gerstenberger, Litchfield, N., Van Dis- sen, R., Berryman, K., Barnes, P., Wallace, L., Bradley, B., Villamor, P., Langridge, R., Lamarche, G., Nodder, S., Reyners, M., Rhoades, D., Smith, W., Nicol, A., Pettinga, J., Clark, K., Jacobs. K. (2012): National Seismic Hazard Model for New Zealand: 2010 Update. Bull. Seis. Soc. America (in press).

Stirling, M. W., Wesnousky, S.G., Shimazaki, K. (1996): Fault trace complexity, cumulative slip, and the shape of the magnitude-frequency distribution for strike-slip faults; a global survey.Geophys. J. Int. 124(3), 833-868. doi: 10.1111/j.1365-246X.1996.tb05641.x.

Tsige, M., Capote, R., Villamor, P. (1997): Superficies de erosión y paleoalteraciones terciarias en Extremadura occidental: In: J. P. Calvo, J. Morales (ed.), Avances en el conocimiento del Terciario Ibérico. Univ. Complutense-Museo Nac. Ciencias Naturales, Madrid: $217-$ 220.

Ugidos Meana, J.M., García de Figuerola, L. C., Bascones, A.L., Martín Herrero, D. (1987a): Hoja geol. num. 598 (Plasencia). Mapa Geológico de España E. 1:50.000. Segunda serie, I.G.M.E., Madrid.

Ugidos Meana, J. M., Garcia de Figuerola, L. C., Bascones, A.L., Martin Herrero, D. (1987b). Hoja geol. num. 596 (Moraleja). Mapa Geológico de España. E. 1:50 000. Segunda serie, I.G.M.E., Madrid.

Ugidos Meana, J. M., Rodriguez Alonso, M. D., Martin Herrero, D., Bascones A.L. (1988): Hoja geol. num. 575 (Hervás). Mapa Geológico de España. E. 1:50.000. Segunda serie, I.G.M.E., Madrid.

UNESCO (2011): World Heritage List. http://whc.unesco.org/en/list/. (Accessed 30-07-2011).

Vegas, R. (1974): Las fallas de desgarre del SO de la Península Ibérica. Boletín Geológico y Minero 85, 153-156.

Vegas, R. (1975): Wrench (transcurrent) fault system of the southwestern Iberian Peninsula: paleogeographic and morphostructural implications. Geologishe Rundschau 64, 266-278.

Villamor, M.P. (2002): Cinemática Terciaria y Cuaternaria de la Falla de Alentejo-Plasencia y su Influencia en la Peligrosidad Sísmica del Interior de la Península Ibérica (Tertiary and Quaternary kinematics of the Alentejo-Plasencia and its influence on sesimic hazard of the interior of Iberian Peninsula; in Spanish). PhD Thesis. University Complutense, Madrid (Spain): 343 p.

Villamor, P., Barrell, D., Litchfield, N., Van Dissen, R., Hornblow, S., Levick, S. (2011): Greendale Fault investigation of surface rupture characteristics for fault avoidance zonation. GNS Science Consultancy Report 2011/121: 58 p.

Villamor, P., Capote, R., Tsige, M. (2004): Basement control on nucleation and geometry of the Alentejo-Plasencia Fault, western Spain. EGU, Nice 2004, Geophysical Research Abstracts 6: 2 p.

Villamor, P., Litchfield, N., Barrell, D., Van Dissen, R., Hornblow, S., Quigley, M., Levick, S., Ries, W., Duffy, B., Begg, J., Townsend, D., Stahl, T., Bilderback, E., Noble, D., Furlong, K., Grant, H. (2012): The 2010 Greendale Fault surface rupture map, Canterbury, New Zealand: Application to land use planning. New Zealand Journal of Geology and Geophysics (in press)

Wells, D.L.; Coppersmith, K.J. (1994): New empirical relationships among magnitude, rupture length, rupture area, and surface displacement. Bull. Seis. Soc. of America 84, 974-1002.

Wesnousky, S.G. (1986): Earthquakes, Quaternary faults and seismic hazard in California. Jour. Geoph. Res. 91, 12.587-12.631. doi:10.1029/JB091iB12p12587.

Ziegler, P.A. (1989): Geodynamic model for Alpine intra-plate compressional deformation in Western and Central Europe. Geological Society London, Special Publications 44, 63-85. doi:10.1144/GSL. SP.1989.044.01.05. 
Villamor et al. / Journal of Iberian Geology 38 (1) 2012: 85-111

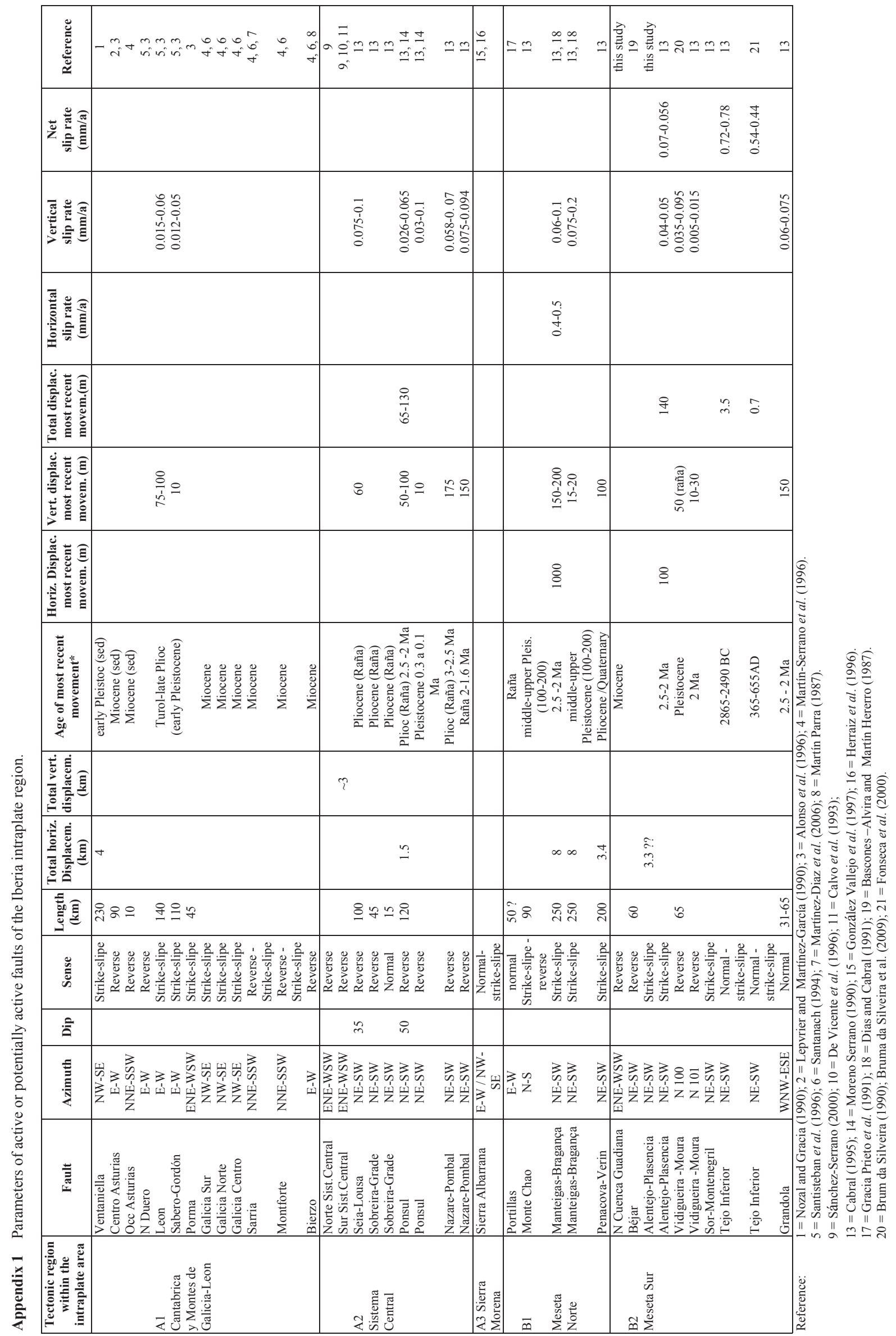




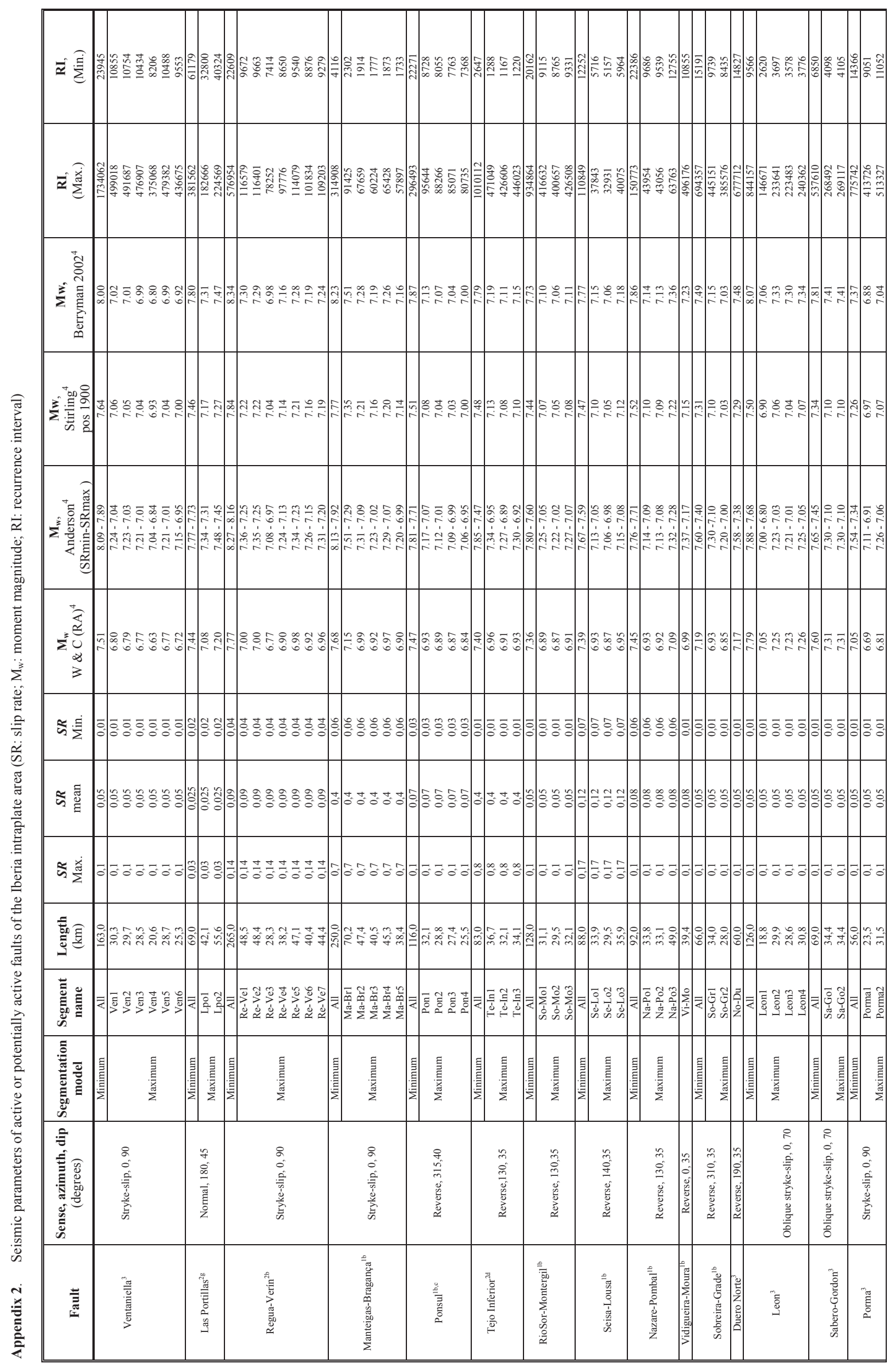



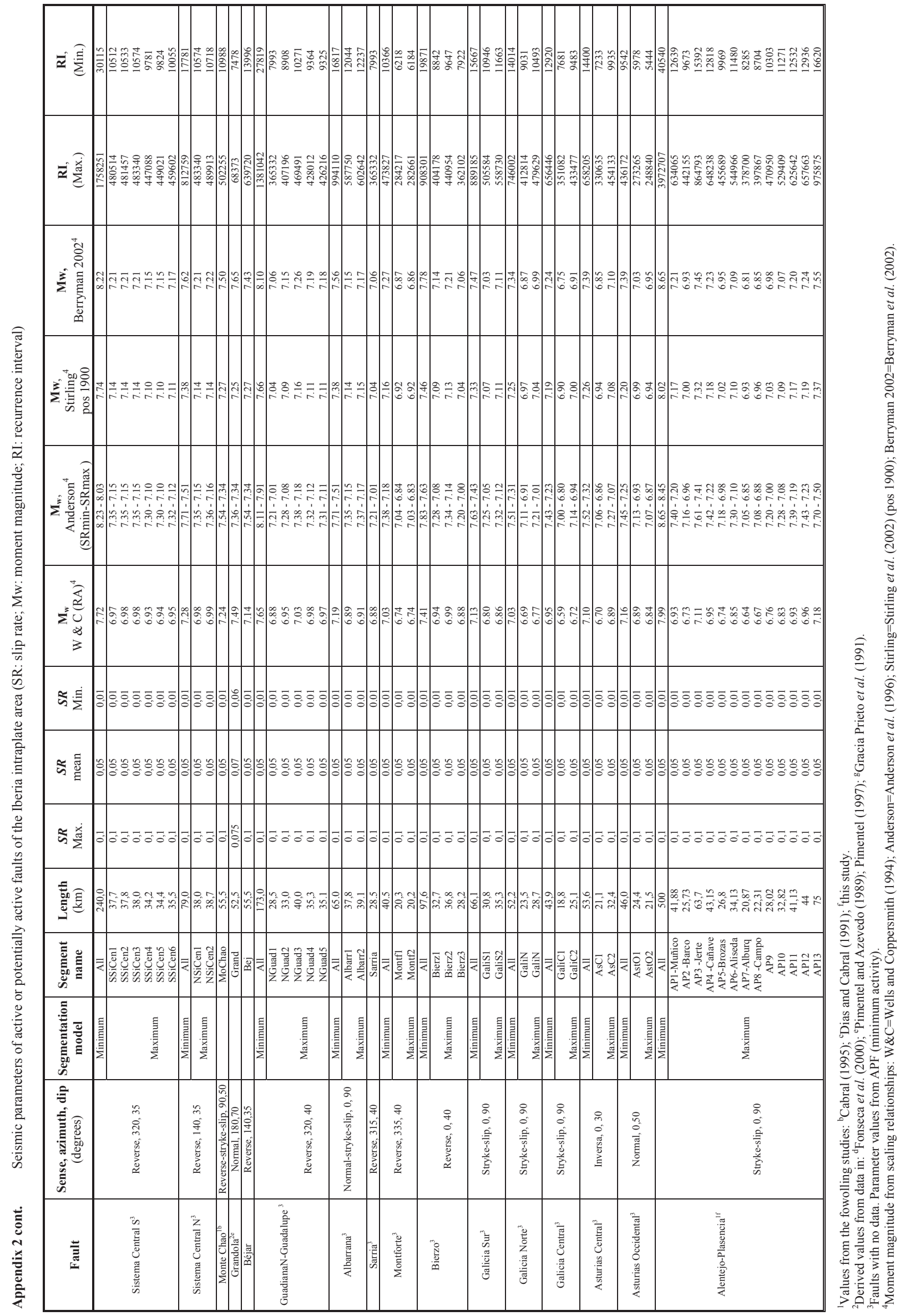